\title{
Water deficit mechanisms in perennial shrubs Cerasus humilis leaves revealed by physiological and proteomic analyses
}

\author{
Zepeng Yin ${ }^{1,2,3 \dagger}$, Jing Ren ${ }^{4 \dagger}$, Lijuan Zhou', Lina Sun ${ }^{1}$, Jiewan Wang ${ }^{1}$, Yulong Liu ${ }^{5}$ and Xingshun Song ${ }^{1,2^{*}}$
}

\begin{abstract}
Background: Drought (Water deficit, WD) poses a serious threat to extensively economic losses of trees throughout the world. Chinese dwarf cherry (Cerasus humilis) is a good perennial plant for studying the physiological and sophisticated molecular network under WD. The aim of this study is to identify the effect of WD on C. humilis through physiological and global proteomics analysis and improve understanding of the WD resistance of plants.
\end{abstract}

Methods: Currently, physiological parameters were applied to investigate C. humilis response to WD. Moreover, we used two-dimensional gel electrophoresis (2DE) to identify differentially expressed proteins in C. humilis leaves subjected to WD (24 d). Furthermore, we also examined the correlation between protein and transcript levels.

Results: Several physiological parameters, including relative water content and Pn were reduced by WD. In addition, the malondialdehyde (MDA), relative electrolyte leakage (REL), total soluble sugar, and proline were increased in WD-treated C. humilis. Comparative proteomic analysis revealed 46 protein spots (representing 43 unique proteins) differentially expressed in C. humilis leaves under WD. These proteins were mainly involved in photosynthesis, ROS scavenging, carbohydrate metabolism, transcription, protein synthesis, protein processing, and nitrogen and amino acid metabolisms, respectively.

Conclusions: WD promoted the $\mathrm{CO}_{2}$ assimilation by increase light reaction and Calvin cycle, leading to the reprogramming of carbon metabolism. Moreover, the accumulation of osmolytes (i.e., proline and total soluble sugar) and enhancement of ascorbate-glutathione cycle and glutathione peroxidase/glutathione s-transferase pathway in leaves could minimize oxidative damage of membrane and other molecules under WD. Importantly, the regulation role of carbohydrate metabolisms (e. g. glycolysis, pentose phosphate pathways, and TCA) was enhanced. These findings provide key candidate proteins for genetic improvement of perennial plants metabolism under WD.

Keywords: Cerasus humilis, Proteomics, ROS, Water deficit, Perennial shrubs, qRT-PCR

\section{Background}

Among potential abiotic stresses, drought (water deficit, WD) is considered to have the largest effect on agricultural productivity, which limits plant growth, distribution and crop yield worldwide [1,2]. It is estimated that the droughty terrestrial areas will redouble by the end of the 21 st century [3]. Thus, it is extremely urgent to determine

\footnotetext{
* Correspondence: sfandi@163.com

${ }^{\dagger}$ Equal contributors

'Department of Genetics, College of Life Science, Northeast Forestry University, Harbin 150040, People's Republic of China

${ }^{2}$ State Key Laboratory of Tree Genetic sand Breeding, Northeast Forestry

University, Harbin 150040, People's Republic of China

Full list of author information is available at the end of the article
}

the mechanisms of plant respond to drought and improve the drought tolerance ability.

During drought stress, a series of metabolic alterations occur, including overproduction of reactive oxygen species (ROS), photoinhibition, denaturation of some proteins such as chloroplast proteins, damage to biofilm structure and functions, and inhibition in protein synthesis $[1,4,5]$. Plants employed series of strategies in response to WD, such as morphology, and physiology metabolisms. The imbalanced light energy conversion and carbon fixation in photosynthetic system may cause accumulation of ROS in plant cells, leading to photo-oxidation damages [2]. An excess of ROS production can lead to oxidative stress in 
plants and negatively impact the normal function of cells [4], which can damage DNA, lipids and proteins [6, 7]. ROS scavenging ability and subsequent injury-reducing effects may correlate with the tolerance to WD [8]. Both enzymatic and non-enzymatic defense systems have evolved in plants for scavenging and detoxifying ROS. The main non-enzymatic antioxidants in plants are soluble ascorbate and glutathione [9]. ROS scavenging enzymes such as ascorbate peroxidase (APX), superoxide dismutase (SOD), catalase (CAT) and peroxidase (POD) also play a very important role. In addition, the accumulation of various osmolytes, such as proline and soluble sugar, play an important protective role during WD, which result in the decrease of osmotic potential [10].

Although there are some researches in woody plants responses to drought in morphological and physiological level [11, 12], few studies were reported on molecular metabolisms. It has been shown that the genes/proteins were induced by WD either directly connected to stress response or implicated in the regulation of gene expression and signal transduction [13-15]. These studies provided important information for understanding WD-responsive gene functions. However, changes at the mRNA and metabolite levels do not always reflect changes at the protein level $[16,17]$. Thus, studying the protein level changes in response to WD is important in woods. Proteomics technologies allow a high-throughput and systemic overview of the cellular physiology in a holistic manner to underscore the underlying metabolic and regulatory mechanisms [18]. It has been reported that WD altered the abundance of proteins involved in carbohydrate and energy metabolism, cellular detoxification, protein processing and degradation, signal transduction, and cell wall strengthening. Most of the previous work on WD related proteomics was performed on annual crops [19]. However, very limited proteomic information on perennial shrubs responses to WD is available. Perennial plants may express stress-responsive proteins associated with longterm adaptation or stress survival, as they must endure/persist through the stress period, unlike annual crops which produce seeds and may die in the case of severe WD $[20,21]$. Thus, developing an adaptation mechanism is critical for the survival of perennial plants in WD environments.

Chinese dwarf cherry (Cerasus humilis (Bge.) Sok.), a species of perennial shrubs, originates in the north of China [22-24]. As most perennial dwarf shrubs in the world, $C$. humilis have the characteristics of being drought-, saline-, alkali-, cold- and sterile resistant, all of which endow the species considerable adaptabilities [23, 24]. Our previous studies showed that exogenous small aliphatic amines (spermidine and spermine) and microorganisms (e.g. photosynthetic bacteria) can alleviate the WD-induced oxidative stress in C. humilis [24]. Besides, the increased expression of $v d e$, a gene encoding violaxanthin deepoxidase in xanthophyll-cycle, confers a great capacity of photoprotection and thus contributes to the survival C. humilis against WD [23]. Although some physiological data and certain genes already give us some information, comparative proteomic analyses can deepen our understanding of plant stress acclimation/tolerance acquisition by providing a detailed picture of functional proteins in C. humilis under WD conditions.

Our objectives were to discover the WD-responsive characteristics of $C$. humilis by using combined physiological and comparative proteomic approaches. We also aimed to determine the role of ROS during this process. To address these questions, we (1) evaluated changes in gas exchange, the enzymes of antioxidants related to ROS, and the osmolytes protections, (2) carried out 2DE based proteomics analyses the different proteins at different time point after WD, (3) investigated the expression changes of some raleted genes by qRT-PCR. These study lead to a better understanding of molecular mechanisms in perennial shrubs under WD.

\section{Methods}

\section{Plant material and treatments}

Cuttings of C. humilis obtained from HuaiRou district, Hebei province, China, were used in the present study. Each cutting was transplanted into the container $(35 \times$ $35 \times 25 \mathrm{~cm}$ ) filled with organic soil, irrigated regularly by Hoagland solution under a $12 \mathrm{~h}$ photoperiod at temperatures ranging from about $17-25^{\circ} \mathrm{C}$, photosynthetic photon flux density (PPFD) of $600 \mu \mathrm{mol} \mathrm{m} \mathrm{m}^{-2} \mathrm{~s}^{-1}$ and the relative humidity of $70-75 \%$ in the greenhouse. Seedlings at the 25-35 leaf stage were divided into two groups: wellwatered plants were irrigated by water every two days (control), and water-deficit (WD) plants did not receive water. All measurements of physiological parameters were carried out on the youngest fully expanded leaves, with at least ten plants per-treatment.

\section{Determination of Relative water content (RWC), MDA, and relative electrolyte leakage (REL)}

RWC was calculated as follows: $\mathrm{RWC}=[(\mathrm{FW}-\mathrm{DW}) /(\mathrm{SW}-$ $\mathrm{DW})] \times 100$. Fresh weight $(\mathrm{FW})$ was measured immediately after harvesting, and saturate weight (SW) was measured right after saturation state immersed in distilled water. Then, the samples were oven-dried at $80{ }^{\circ} \mathrm{C}$ for $15 \mathrm{~min}$, then vacuum-dried at $60{ }^{\circ} \mathrm{C}$ to constant weight and the DWs were recorded. The REL was measured by an electrical conductivity method [25].

Measurement of photosynthesis and chlorophyll fluorescence Net photosynthetic rates (Pn), stomata conductance (Gs), and intercellular $\mathrm{CO}_{2}(\mathrm{Ci})$ of leaves were determined during 8:30-11:30 h using a gas-exchange system (LI-6400; LICOR 
Biosciences, Lincoln, USA) on 24 days WD treatment. The photosynthetically active radiation was $1000 \mu \mathrm{moL} \mathrm{m}{ }^{-2} \mathrm{~s}^{-1}$ (saturation light). The ambient $\mathrm{CO}_{2}$ concentration was $360 \pm 10 \mu \mathrm{mol} \mathrm{moL}{ }^{-1}$, and the air temperature and humidity were about $24{ }^{\circ} \mathrm{C}$ and $50 \%$. Measurements were repeated at least five times for each treatment and the averages were recorded.

The maximum photochemical efficiency of PSII (Fv/ Fm) was measured using a pulse modulation chlorophyll fluorometer (FMS-2, Hansatech, UK) after 30 min dark adaptation [26].

\section{Determination of total soluble sugar, proline, $\mathrm{H}_{2} \mathrm{O}_{2}$ content and $\mathrm{O}_{2}^{-}$generation rate}

Total soluble sugar and proline contents were determined using an anthrone reagent and ninhydrin reaction, respectively, as previously described [27].

To evaluate the levels of ROS in leaves, $\mathrm{H}_{2} \mathrm{O}_{2}$ content and $\mathrm{O}_{2}^{-}$generation rates were measured. Briefly, leaf tissue was ground in $0.1 \%$ trichloroacetic acid. The homogenate was centrifuged at $15,000 \mathrm{~g}$ for $15 \mathrm{~min}$ at $4{ }^{\circ} \mathrm{C}$ and the supernatant was collected for $\mathrm{H}_{2} \mathrm{O}_{2}$ measurement. $\mathrm{H}_{2} \mathrm{O}_{2}$ content was determined spectrophotometrically after reaction with potassium iodide [28], and $\mathrm{O}_{2}^{-}$generation rates were measured using a hydroxylamine oxidization method [29].

\section{Determination of antioxidant enzyme activities}

The activity of antioxidant enzyme assays, including superoxide (SOD), catalase (CAT), peroxidase (POD), ascorbate peroxidase (APX), monodehydroascorbate reductase (MDHAR), dehydroascorbate reductase (DHAR), glutathione reductase (GR), glutathione S-transferase (GST), glycolate oxidase (GO) and glutathione peroxidase (GPX), was assayed following the method of [30] and [24]. In all enzyme preparations, protein was quantified following by [31] using bovine serum albumin as a standard.

\section{Protein sample preparation, 2DE, and image analysis}

Protein extraction and two-dimensional electrophoresis (2DE) separation were performed as previously described, with minor modifications [30]. Briefly, treated leaves (1g) was ground in liquid nitrogen, and total soluble proteins were extracted at $4^{\circ} \mathrm{C}$ in $8 \mathrm{~mL}$ of extraction buffer containing $100 \mathrm{mM}$ Tris- $\mathrm{HCl}$ buffer ( $\mathrm{pH}$ 8.8),10 mM EDTA, 0.9 $\mathrm{M}$ sucrose, and $0.4 \%$ mercaptoethanol. Homogenates were centrifuged at $15000 \mathrm{~g}$ for $15 \mathrm{~min}$ at $4^{\circ} \mathrm{C}$, and the supernatants were added to $5 \mathrm{vol}$ of $100 \mathrm{mM}$ ammonium sulfate/ methanol. Samples were maintained at $-20{ }^{\circ} \mathrm{C}$ for $4 \mathrm{~h}$ and then were centrifuged at $20000 \mathrm{~g}$ for $15 \mathrm{~min}$ at $4{ }^{\circ} \mathrm{C}$. The resulting pellets were washed with $80 \%$ acetone containing at $-20{ }^{\circ} \mathrm{C}$ for $1 \mathrm{~h}$, and the $100 \%$ acetone wash once after centrifugation. The final pellets were vacuum-dried and dissolved in $7 \mathrm{M}$ urea, $40 \mathrm{mM}$ DTT, 4\% (w/v) CHAPS, and
$2 \%(w / v)$ ampholyte ( $\mathrm{pH} 3-10)$. Samples in ampholyte were vortexed thoroughly for $1 \mathrm{~h}$ at room temperature and then were centrifuged at $35000 \mathrm{~g}$ for $20 \mathrm{~min}$ at $20{ }^{\circ} \mathrm{C}$. Supernatants then were collected for 2DE experiments [32]. Protein concentration was determined using a Quant-kit according to manufacturer's instructions (GE Healthcare, USA). Extracted proteins were first separated by isoelectric focusing (IEF) using gel strips ( $\mathrm{pH}$ 4-7 linear, $13 \mathrm{~cm}$ ) (GE Healthcare,USA). Following IEF, proteins were separated by sodium dodecyl sulfate-polyacrylamide gel electrophoresis (SDS-PAGE) using $12.5 \%(\mathrm{w} / \mathrm{v})$ polyacrylamide. Gel strips then were rehydrated in $450 \mu \mathrm{L}$ of dehydration buffer containing $1600 \mu \mathrm{g}$ of total proteins and a trace of bromophenol blue for $26 \mathrm{~h}$. Gel strips were focused at $80 \mathrm{kV} / \mathrm{h}$ and $20{ }^{\circ} \mathrm{C}$ using the PROTEAN IEF system (Bio-Rad,USA) and then were equilibrated for $15 \mathrm{~min}$ in equilibration buffer (6 M urea, $0.5 \mathrm{M}$ Tris [pH 8.8], 2\% [w/v] SDS, 30\% [v/v] glycerol). Gel strips then were placed over $12.5 \%(\mathrm{w} / \mathrm{v})$ SDS-PAGE gels for 2DE. Gel electrophoresis was performed at $25 \mathrm{~mA}$ for $5 \mathrm{~h}$. Gels were stained using Coomassie Brilliant Blue (CBB). After staining, gels were scanned using an ImageScanner III (GE Healthcare, USA) at a resolution of $300 \mathrm{dpi}$ and 16-bit grayscale pixel depth. The images were analyzed with ImageMaster 2D software (version 6.0) (GE Healthcare, USA). The average vol\% values were calculated from three technical replicates to represent the final vol\% values of each biological replicate. The volume of each spot changed more than 1.5-fold among the treatments and a $p<0.05$ were considered to be differentially expressed spots.

\section{Protein identification and database searching}

Protein spots displaying significant changes in abundance were excised manually from colloidal CBB stained 2DE gels using sterile pipette tips. Briefly, spots cut out of the gels were destained twice with $100 \mathrm{mM} \mathrm{NH}_{4} \mathrm{HCO}_{3}, 50 \% \mathrm{ACN}$ at $37{ }^{\circ} \mathrm{C}$ for $20 \mathrm{~min}$ in each treatment. After dehydration with $100 \% \mathrm{ACN}$ and drying, the gel pieces were preincubated in 10-20 $\mu \mathrm{L}$ of trypsin solution $(10 \mathrm{ng} / \mu \mathrm{L})$ for $1 \mathrm{~h}$. Then adequate digestion buffer $\left(40 \mathrm{mM} \mathrm{NH} \mathrm{HCO}_{3}\right.$, $10 \% \mathrm{ACN}$ ) was added to cover the gel pieces, which were extracted using Milli-Q water followed by double $1 \mathrm{~h}$ extraction with 50\% ACN and 5\% TFA. The combined extracts were dried in SpeedVac concentrator (Thermo Scientific) at $4{ }^{\circ} \mathrm{C}$. The samples were then subjected to mass spectrometry [30].

The MS spectra were acquired using a MALDI-TOFMS/MS (AB SCIEX TOF/TOF: trademark: 5800 system). A Mass standard kit (Applied Biosystems, USA) and a standard BSA digest (Sigma-Aldrich, USA) were used for MS and MS/MS calibrations and fine-tuning the resolution and sensitivity of the system as previously described [33]. The mass error was below $30 \mathrm{ppm}$ at both MS and MS/MS mode and the resolution was 
more than 25000 . The MS/MS spectra were searched against the NCBInr protein databases (http://www.ncbi.nlm. nih.gov/)(5,222,402 sequence entries in NCBI) using Mascot software (Matrix Sciences, London, UK). The taxonomic category was green plants. The searching criteria were according to [34]. The searching criteria include mass tolerance for precursor ions of $0.3 \mathrm{Da}$, mass tolerance for fragment ions of $100 \mathrm{ppm}$, one missed cleavage allowed, carbamidomethylation of cysteine as a fixed modification, and oxidation of methionine as a variable modification. To obtain high confident identification, proteins had to meet the following criteria: the top hits on the database searching report, a probability-based MOWSE score greater than 43 ( $p$-value $<0.01$ ), and more than two peptides matched with nearly complete $y$-ion series and complementary b-ion series present.

\section{Protein classification and hierarchical cluster analysis}

To determine the functions of identified proteins, we searched against the NCBI database (http://www.ncbi.nlm. nih.gov/) (accessed on 8 August 2012) and UniProt database (http://www.ebi.uniprot.org/). By integrative analysis of all the information collected from aforementioned processed, each protein was classified into certain functional category defined by us. Log (base 2) transformed ratios were used forhierarchical clustering analysis using Cluster 3.0 available onthe Internet (http://bonsai.hgc.jp/ $\sim$ mdehoon/software/cluster/software.htm), and the results were visualized using Java TreeView (http://jtreeview. sourceforge.net/).

\section{Protein subcellular location prediction}

The subcellular location of the identified proteins was predicted using five internet tools: (1) YLoc (http://abi.in f.uni-tuebingen. de/Services/YLoc/webloc.cgi), confidence score $\geq 0.7$; (2) LocTree3 (https://rostlab.org/services/loc tree3/), expected accuracy $\geq 80 \%$; (3) ngLOC (http://geno me.unmc.edu/ngLOC/ index.html), probability $\geq 80 \%$; (4) TargetP (http://www.cbs.dtu.dk/services/TargetP/), reliability class $\leq 3$; (5) Plant-mPLoc (http://www.csbio.sjtu.e du.cn/bioinf/plant-multi/) no threshold value in PlantmPLoc. Only the consistent predictions from at least two tools were accepted as a confident result. For the inconsistent prediction results among five tools, subcellular localizations for corresponding proteins were predicted based on literatures.

\section{Total RNA extraction, reverse transcription and qReal- Time (qRT)-PCR analysis}

Based on the findings of proteomic analysis, we chose 12-responsive proteins which might be the underlying regulator of WD tolerance for $\mathrm{qRT}$-PCR analysis for the verification of proteomic data. Total RNA from abdominal adipose tissue was isolated using Trizol reagent. Onemicrogram total RNA was performed in reverse transcription with Revert Aid Reverse Transcriptase (Fermentas) and Oligo d $(\mathrm{T})$ primers $(\mathrm{TaKaRa})$. Reverse transcription conditions for each cDNA amplification were $65^{\circ} \mathrm{C}$ for 5 min, $37{ }^{\circ} \mathrm{C}$ for $52 \mathrm{~min}$, and $70{ }^{\circ} \mathrm{C}$ for $15 \mathrm{~min}$. Real-time RT-PCR was carried out using the Real-time PCR System (Roche Light Cycler 480 II, Switzerland) and SYBR Premix Ex Taq (TaKaRa). The primers used for the PCR are listed in Additional file 1: Table S1. Values represent the mean of three biological replicates and two technical replicates. The relative gene expression levels were calculated by the $2^{-\Delta \Delta t}$ method [35].

\section{Data analysis}

All results were presented as means \pm standard error (SE) of at least three replicates. Results were analyzed by oneway ANOVA using the statistical software SPSS 17.0 (SPSS Inc. Chicago, IL, USA). Posthoc comparisons were tested using the LSD test at a significance level of $p<0.05$.

\section{Results}

\section{Effects of WD on photosynthesis}

The photosynthesis indexes of $C$. humilis under WD were analyzed. After 24 days of treatment, $\mathrm{Pn}, \mathrm{Gs}$ and $\mathrm{Ci}$ in $\mathrm{C}$. humilis leaves under WD were significantly lower than those under control conditions (Table 1). In addition, chlorophyll fluorescence parameters were monitored to determine the performance of photosystem II (PSII) photochemistry. Fv/Fm were not significantly altered after 6 days WD, but were significantly reduced by 7 and $14 \%$ at 12 and 24 days WD, respectively, as compare with controls (Table 1).

Table 1 Effects of Pn, Gs, Ci and Fv/Fm of C. humilis under WD for 0, 6, 12, and $24 \mathrm{~d}$

\begin{tabular}{|c|c|c|c|c|c|c|c|c|}
\hline \multirow{3}{*}{$\begin{array}{l}\text { Treatment } \\
\text { time (d) }\end{array}$} & \multirow{2}{*}{\multicolumn{2}{|c|}{$\begin{array}{l}\mathrm{Pn} \\
\left(\mu \mathrm{mol} \mathrm{CO} 2 \cdot \mathrm{m}^{-2} \cdot \mathrm{s}^{-1}\right)\end{array}$}} & \multirow{2}{*}{\multicolumn{2}{|c|}{$\begin{array}{l}\text { Gs } \\
\left.\left(\mu \mathrm{mol} \mathrm{H} \mathrm{H}_{2} \mathrm{O}_{2} \cdot \mathrm{m}^{-2} \cdot \mathrm{s}^{-1}\right)\right)\end{array}$}} & \multirow{2}{*}{\multicolumn{2}{|c|}{$\begin{array}{l}\mathrm{Ci} \\
\left(\mu \mathrm{mol} \mathrm{CO}_{2} \cdot \mathrm{m}^{-2} \cdot \mathrm{s}^{-1}\right)\end{array}$}} & \multicolumn{2}{|l|}{$\mathrm{Fv} / \mathrm{Fm}$} \\
\hline & & & & & & & \multirow[b]{2}{*}{ Control } & \multirow[b]{2}{*}{ WD } \\
\hline & Control & WD & Control & WD & Control & WD & & \\
\hline 0 & $22.3 \pm 0.4 a$ & $21.6 \pm 0.6 a$ & $187 \pm 22 \mathrm{a}$ & $192 \pm 23 a$ & $352 \pm 7 a$ & $338 \pm 26 a$ & $0.838 \pm 0.03 a$ & $0.829 \pm 0.013 a$ \\
\hline 6 & $21.9 \pm 0.4 a$ & $18.6 \pm 0.8 b$ & $199 \pm 11 a$ & $177 \pm 16 a$ & $345 \pm 9 a$ & $321 \pm 12 a b$ & $0.837 \pm 0.05 a$ & $0.796 \pm 0.018 a b$ \\
\hline 12 & $22.6 \pm 0.7 a$ & $15.3 \pm 0.9 c$ & $189 \pm 12 a$ & $116 \pm 9 c$ & $342 \pm 12 \mathrm{a}$ & $311 \pm 21 b c$ & $0.830 \pm 0.06 a$ & $0.774 \pm 0.017 b$ \\
\hline 24 & $20.8 \pm 1.1 a$ & $13.6 \pm 0.1 d$ & $187 \pm 33 a$ & $86 \pm 11 d$ & $354 \pm 14 a$ & $288 \pm 17 c$ & $0.822 \pm 0.06 a$ & $0.716 \pm 0.022 c$ \\
\hline
\end{tabular}

Each value is the mean \pm SE of five independent experiments. The different small letters indicate significant difference $(p<0.05)$ under WD 
Effects of WD on leaf relative water content (LRWC) and membrane lipid peroxidation

WD resulted in a gradual decrease in LRWC in C. humilis, although there were no significantly changes of LRWC in WD treated plants in the early treatment period (6 d), as compared with controls. At 12 and $24 \mathrm{~d}$ of WD, LRWC was decreased to 85 and $71 \%$ of controls, respectively (Fig. 1a).

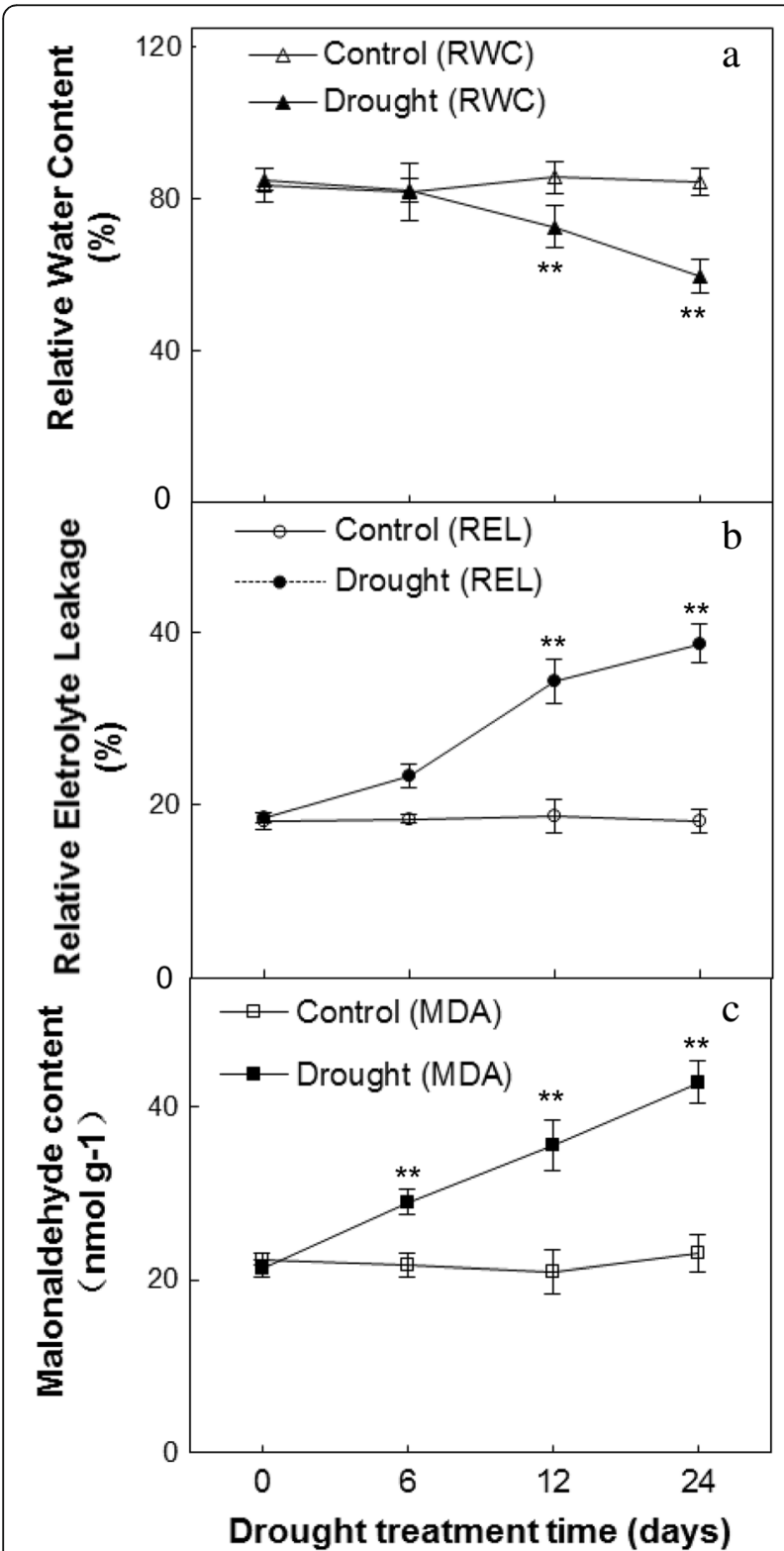

Fig. 1 Effects of water deficit on leaf relative water content (LRWC) (a), relative electrolyte leakage (REL) (b), and malondialdehyde (MDA) (c) in C. humili leaves. Values are presented as means \pm SE $(n=3)$. The values were determined under control and water deficit treatment at $0,6,12$, and 24 days. ${ }^{*}$ and ${ }^{* *}$ indicate values that differ significantly from controls at $p \leq 0.05$ and $p \leq 0.01$, respectively, according to LSD test
To determine the levels of membrane integrity and permeability of the cell membrane in $C$. humilis seedlings during WD, the status of REL and MDA were monitored. Leaf REL and MDA content increased slightly in the early WD period (6 d) (Fig. 1b, c), and C. humilis plants had a significantly high REL level by the end of WD treatment $(24 \mathrm{~d})$. These imply that the membrane integrity of WD plants was destroyed and the electrolyte inside of cells was come out to some extents.

\section{Effects of WD on soluble sugar and proline}

Under WD, plants could synthesize compatible lowmolecular weight organic solutes, such as proline and soluble sugar to alleviate WD-induced osmotic stress. In this study, the soluble sugar content increased significantly during the whole WD period compared to controls (Fig. 2). The proline content did not display significantly changes in the early treatment period, while they showed dramatic increases upon 12 and $24 \mathrm{~d}$ of WD (Fig. 2). The accumulation of soluble sugar and proline contents may contribute to maintain osmotic balance under WD.

Effects of WD on $\mathrm{H}_{2} \mathrm{O}_{2}$ content, the generation rate of $\mathrm{O}_{2}^{-}$ and antioxidant enzyme activities

In the present study, the rate of $\mathrm{O}_{2}^{-}$generation and $\mathrm{H}_{2} \mathrm{O}_{2}$ contents were increased gradually on time for $C$. humilis leaves subjected to WD (Fig. 3a), suggesting that oxidative stress was occurred. The activity of SOD, a key enzyme of scavenging ROS, was enhanced in $C$. humilis leaves exposed to WD (Fig. 3b), which might enable the dismutation of superoxide into oxygen and $\mathrm{H}_{2} \mathrm{O}_{2}$ timely. Plants possess a complex mechanism of enzymatic antioxidants (e.g. POD, CAT, GPX, APX, MDHAR, DHAR, GR, and GST) that protect cells from oxidative damage by scavenging ROS. Thus, their activities were examined in this study. The activities of POD, CAT, APX, DHAR and GST were significantly increased in the whole WD period (Fig. 3b, c, d, e, f). The activities of GPX, MDHAR, and GR were increased after $12 \mathrm{~d}$ of WD conditions (Fig. 3c, d, e). In contrast, the GOX activities were decreased under WD (Fig. 3f), although the decrease extents were less significant as compared to other enzymes. In the whole level, the induction of enzymes activities under WD implies that they play a crucial role in defending against the oxidative stress and cell damage induced by WD.

\section{Identification, functional categorization and subcellular} location of different changed proteins in response to WD Based on the results of biochemical assays, we chose 0 , 12 , and $24 \mathrm{~d}$ WD samples for proteomic analysis. Total soluble proteins from control and WD-treated C. humilis leaves were separated and imaged, respectively (Fig. 4). Approximately, 700 Coomassie Brilliant Blue-stained 


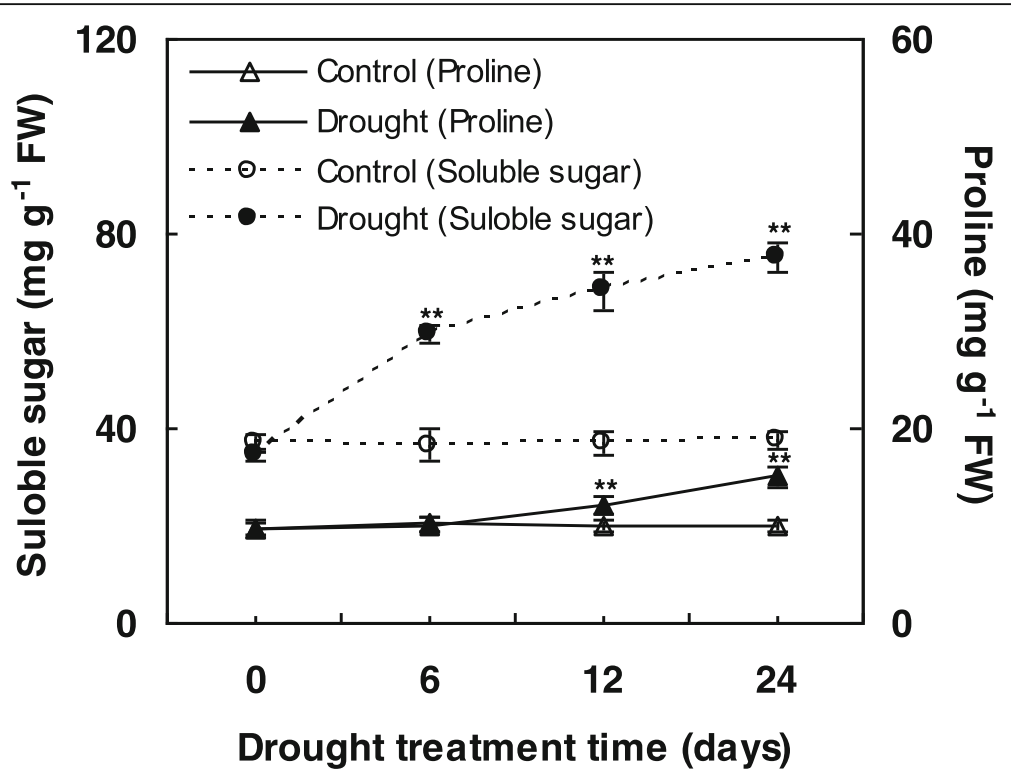

Fig. 2 Effects of water deficit on leaf soluble sugar and proline contents in C. humilileaves. Values are presented as means \pm SE. The values were determined under control and water deficit treatment at $0,6,12$, and 24 days. ${ }^{*}$ and ${ }^{* *}$ indicate values that differ significantly from controls at $p \leq 0.05$ and $p \leq 0.01$, respectively, according to LSD test

protein spots were detected on the pI 4-7 gels. Only the protein spots that exhibited reproducible changes under WD (average fold changes $>1.5$ or $<0.6, p$-value $<$ $0.05)$ were retained for further analysis. A total of 46 protein spots showed significant changes in WD samples as compared to control leaves (Table 2). The differentially expressed protein spots were successfully identified by using tandem MS, of which 46 spots represented 43 unique proteins (Table 2, Additional file 2: Table S2). Further examination of their electrophoretic patterns indicated that their inferred mass or isoelectric point values differed, perhaps owing to post-translational modification or degradation. To further examine the differentially expressed proteins, the identified proteins were assigned to Gene Ontology terms (Table 2, Additional file 2: Table S2). The 46 IDs were classified into 8 categories (Fig. 5a), covering a wide range of biological processes, which include photosynthesis (26\%), stress and defense (13\%), carbohydrate and energy metabolism (15\%), transcription related proteins $(7 \%)$, protein synthesis and turnover $(11 \%)$, amino acid metabolism (24\%), cell wall related (2\%), and cell division (2\%), respectively. In total, 22 significantly changed proteins were predicted to be localized in chloroplast, 10 in cytoplasm, two in mitochondria, two in nucleus, eight in secreted, and two in vacuole (Fig. 5b, Additional file 3: Table S3).

\section{Hierarchical clustering of different changed proteins in response to WD}

To study protein expression characteristics in each functional category, hierarchical clustering analysis was performed that yielded two main clusters (Fig. 6). Cluster I included 40 IDs (Fig. 6), the levels of which were increased under WD. These proteins were divided into two subclusters: Subcluster I-1 contained the proteins mainly increased significantly under $24 \mathrm{~d}$ WD, while subcluster I-2 contained the proteins mainly increased under $12 \mathrm{~d}$ WD. The proteins in cluster I covered seven function categories. The remaining six IDs were grouped into cluster II, representing decreased proteins under WD. Cluster II contained two subclusters: Subcluster II-1 contained 3 IDs induced either at 12 and $24 \mathrm{~d}$ of WD, while subcluster II-2 included 3 proteins significantly increased only at $12 \mathrm{~d}$ of WD (Fig. 6). When examined proteins in each cluster, most of increased IDs were involved in photosynthesis and ROS scavenging and were mainly included in cluster I, whereas carbohydrate and cell division were decreased and present in cluster II.

\section{Homologous gene expression of different changed proteins}

To determine whether changes of gene transcription levels correlated with changes of protein levels, a qRT-PCR analysis of 12 genes was performed (Fig. 7). The results demonstrated that nine genes, namely carbonic anhydrase (CA), Ribose 5-phosphate isomerase (Rpi), dehydroascorbate reductase (DHAR), glutathione peroxidase (GPX), malic enzyme (ME), transketolase 1 (TK), heat shock protein 70 (HSP 70), 20S proteasome, and acidic endochitinase (Echi) showed consistent expressional trends with their homologous proteins (Fig. 7, Table 2). They were involved in photosynthesis, stress and defense, carbohydrate and 


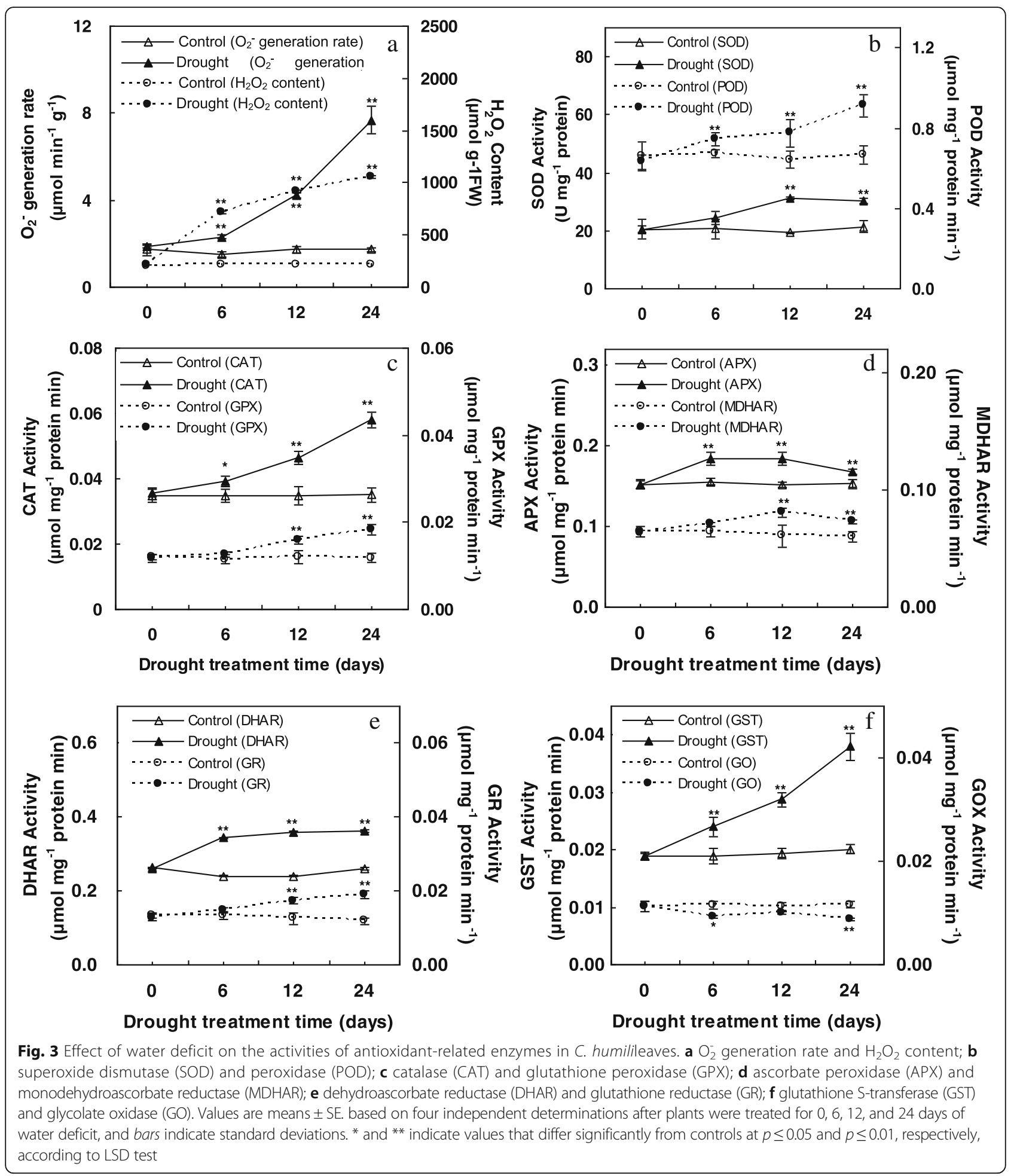

energy metabolism, protein synthesis and turnover, and cell wall related, respectively. In addition, three genes, namely cytosolic ascorbate peroxidase (APX19), triosephosphate isomerase (TIM), and RNA recognition motif (RRM) appeared opposite expressional trends with homologous proteins (Fig. 7, Table 2). They were involved in stress and defense, carbohydrate and energy metabolism, and transcription, respectively. The results of correlation analysis indicate that the aforementioned metabolic processes were modulated by post-transcriptional and/or 

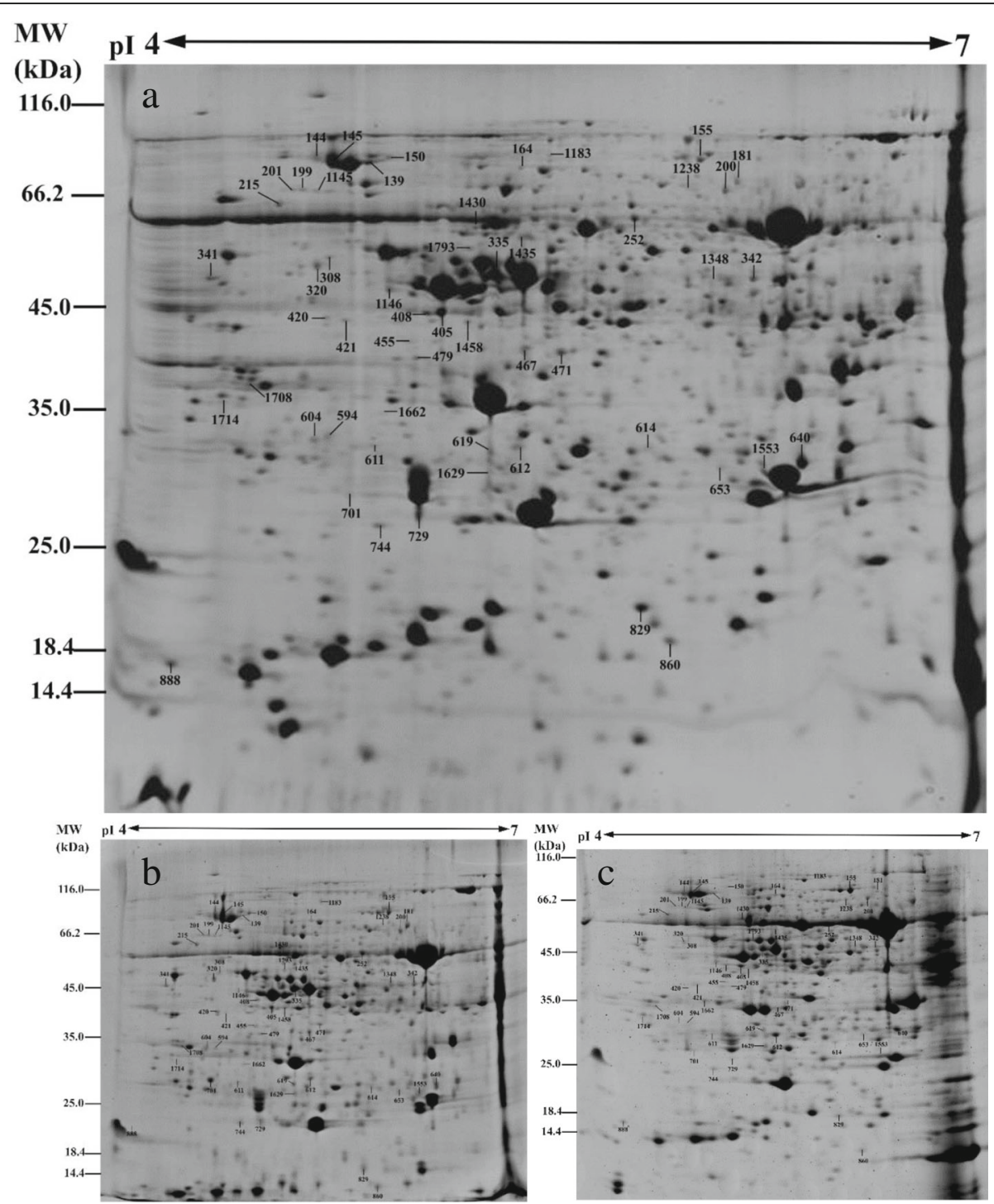

Fig. 4 Representative 2-DE gel image of proteins in response to water deficit from C. humilileaves. a control; b 12 days after water deficit; c 24 days after water deficit. Proteins were separated on $13 \mathrm{~cm}$ IPG strips (pl 4-7 linear gradient) using IEF in the first dimension, followed by $12.5 \%$ SDS-PAGE gels in the second dimension. The 2-DE gel was stained with Coomassie Brilliant Blue. Molecular weight (MW) in kDa and pl of proteins are indicated on the left and top of the gel, respectively. A total of 46 differentially expressed proteins identified by MALDI-TOF-MS/MS were marked with numbers on the gel, and detailed information can be found in Additional file 2: Table S2 and Table 1

post-translational regulation during WD. The inconsistent abundances of transcripts and proteins in WD also support the notion that pre-synthesized mRNA and proteins would function in the process of WD.

\section{Discussion}

WD is the main limiting factor for plants growing in arid areas. Biochemical, physiological and molecular influences on plants are wide-spread during WD and can be divided into three aspects: growth control, stress damage control and osmotic homeostasis [2, 36]. An integrated proteomics, biochemical, physiological and morphological approach was used for our research to investigate these aspects of WD responses in C. humilis.

\section{Photosynthetic acclimation to WD}

In C. humilis seedlings, Gs and $\mathrm{Ci}$ were declined gradually under WD, indicating that the decrease in Pn (Table 1) may be the result of a stomatal limitation [37]. Based on our determination of chlorophyll fluorescence, $\mathrm{Fv} / \mathrm{Fm}$ significantly declined in response to WD at 12 and 24 days (Table 1), suggesting that WD causes photoinhibition of PSII. To our surprise, we found that 10 out of 12 light reaction and Calvin cycle-related proteins, including a carbonic anhydrase (CA), seven ribulose-1,5-bisphosphate 
Table 2 Relative protein content changes in C. humilis leaves under water deficit

\begin{tabular}{|c|c|c|c|c|c|c|c|c|c|}
\hline $\begin{array}{l}\text { Spot } \\
\text { No. }\end{array}$ & Protein name ${ }^{(b)}$ & $\begin{array}{l}\text { Subcellular } \\
\text { location(c) }\end{array}$ & Species $^{(a)}$ & $\begin{array}{c}\mathrm{gi} \\
\text { Number }\end{array}$ & $\begin{array}{l}\text { Thr. } \\
\text { MW } \\
\text { (Da) } \\
/ \mathbf{p I}^{(t)}\end{array}$ & $\begin{array}{l}\text { Exp. } \\
\text { MW } \\
\text { (Da) } \\
/ \mathbf{p I}^{(\ell)}\end{array}$ & Sco & QM & $\begin{array}{l}\mathbf{V} \% \pm \mathbf{S E}^{j j} \\
0,12,24(\mathrm{~d})\end{array}$ \\
\hline 653 & $\begin{array}{l}\text { Photosynthesis (12) } \\
\text { Carbonic anhydrase (CA) }\end{array}$ & $\mathrm{CH}$ & & 29733243 & & & 77 & 3 & \\
\hline 1146 & Ribulose-1,5-bisphosphate carboxylase/oxygenase & $\mathrm{Chl}$ & $\begin{array}{l}\text { Arabiaopsis } \\
\text { lyrata subsp. } \\
\text { Heterolepis }\end{array}$ & $\begin{array}{l}297336434 \\
125857653\end{array}$ & $\begin{array}{l}29,171 / \\
6.1 \\
51,796 /\end{array}$ & $\begin{array}{l}40.359 / \\
6.21 \\
80,159 /\end{array}$ & $\begin{array}{l}77 \\
285\end{array}$ & $\begin{array}{l}3 \\
12\end{array}$ & \\
\hline 308 & Ribulose-1,5-bisphosphate carboxylase/oxygenase & $\mathrm{Chl}$ & Malus $x$ & 415852 & $48,217 /$ & $60,254 /$ & 76 & 7 & \\
\hline 1145 & $\begin{array}{l}\text { large subunit (RuBisCO LSU) } \\
\text { Ribulose-1,5-bisphosphate carboxylase/oxygenase }\end{array}$ & Chl & $\begin{array}{l}\text { domestica } \\
\text { Bongardia }\end{array}$ & 7240504 & $\begin{array}{l}8.2 \\
52,269 /\end{array}$ & $\begin{array}{l}4.74 \\
79,338 /\end{array}$ & 237 & 13 & \\
\hline 201 & $\begin{array}{l}\text { lagre subuntt (RuBisCO LSU) } \\
\text { Ribulose-1,5-bisphosphate carboxylase/oxygenase }\end{array}$ & Chl & $\begin{array}{l}\text { chrrsogonum } \\
\text { Vanilla }\end{array}$ & 39655299 & $\begin{array}{l}6.13 \\
49,077 /\end{array}$ & $\begin{array}{l}4.11 \\
78,475 / \\
467\end{array}$ & 289 & 10 & \\
\hline 199 & $\begin{array}{l}\text { Ribulose-1, } 5 \text {-bisphosphate carboxylase/oxygenase } \\
\text { latge subunit (RuBisCO LSU) }\end{array}$ & $\mathrm{Chl}$ & $\begin{array}{l}\text { Loeseneriella } \\
\text { sp. Chase }\end{array}$ & 9909955 & $\begin{array}{l}52,296 / \\
6,04\end{array}$ & $\begin{array}{l}80,473 / \\
4.69\end{array}$ & 212 & 11 & \\
\hline 215 & 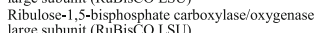 & Chl & Cremastosperm & 54660772 & $\begin{array}{l}51,530 / \\
678\end{array}$ & $\begin{array}{l}75,683 / \\
461\end{array}$ & 512 & 15 & \\
\hline 252 & $\begin{array}{l}\text { Ribulose-1,5-bisphosphate carboxylase/oxygenase } \\
\text { large subunit }(R u B i s C O L S U)\end{array}$ & Chl & $\begin{array}{l}\text { a lelophylum } \\
\text { Astripomoea } \\
\text { grantii }\end{array}$ & 21633967 & $\begin{array}{l}6.18 \\
52,502 / \\
6,57\end{array}$ & $\begin{array}{l}4.01 \\
67,4321 \\
5.86\end{array}$ & 761 & 20 & \\
\hline 611 & $\begin{array}{l}\text { Chlorophyll a-b binding protein 3,chloroplastic } \\
(\mathrm{CAB})\end{array}$ & Chl & Glycine max & 255647962 & $\begin{array}{l}27.959 / \\
5.29\end{array}$ & $\begin{array}{l}36.452 / \\
4.93\end{array}$ & 83 & 4 & \\
\hline 455 & Ribose 5-phosphate isomerase (Rpi) & Chl & Vitis vinifera & 225451267 & $\begin{array}{l}33239 / \\
522\end{array}$ & $\begin{array}{l}37,324 / \\
5,08\end{array}$ & 105 & 4 & \\
\hline 408 & $\begin{array}{l}\text { Sedoheptulose-1,7-bisphosphatase, chloroplastic } \\
\text { (SBPase) }\end{array}$ & $\mathrm{Chl}$ & $V$. vinifera & 225466690 & $\begin{array}{l}5.2288 / \\
42,95\end{array}$ & $\begin{array}{l}35,424 / \\
5,14\end{array}$ & 147 & 4 & \\
\hline 405 & $\begin{array}{l}\text { Sedoheptulose-1,7-bisphosphatase, chloroplastic } \\
\text { (SBPase) }\end{array}$ & $\mathrm{Chl}$ & V. vinifera & 225466690 & $\begin{array}{l}52,8981 \\
5.95\end{array}$ & $\begin{array}{l}55,234 / \\
5.21\end{array}$ & 238 & 5 & \\
\hline 1662 & $\begin{array}{l}\text { Stress and defense (6) } \\
\text { Copper/zinc superoxide dismutase copper } \\
\text { chaperone prcursor (SOD) }\end{array}$ & $\mathrm{Sec}$ & $\begin{array}{l}\text { Populus } \\
\text { trichocarpa }\end{array}$ & 222841882 & $\begin{array}{l}34,529 / \\
5.47\end{array}$ & $\begin{array}{l}42,342 / \\
4,93\end{array}$ & 104 & 3 & \\
\hline 1435 & Peroxidase 1 (POD) & $\mathrm{Sec}$ & Phaseolus & 73913500 & $32,325 /$ & $\begin{array}{l}49,243 / \\
5,46\end{array}$ & 289 & 6 & \\
\hline 640 & Cytosolic ascorbate peroxidase APX19 (APX) & Cyt & $\begin{array}{l}\text { Fragariax } \\
\text { ananassa }\end{array}$ & 5442416 & $\begin{array}{l}8.064 / \\
27.364 /\end{array}$ & $\begin{array}{l}29.253 / \\
6.39\end{array}$ & 207 & 3 & \\
\hline 1629 & Dehydroascorbate reductase 1 (DHAR) & Sec & Malus $x$ & 225380890 & $29,487 /$ & $34,435 /$ & 97 & 2 & \\
\hline 744 & Glutathione peroxidase 1 (GPX) & $\mathrm{Chl}$ & $\begin{array}{l}\text { Vomentica } \\
\text { V. vinifera }\end{array}$ & 225426405 & $19,447 /$ & $28,453 /$ & 149 & 2 & \\
\hline 829 & $\begin{array}{l}\text { Pathogenesis-related protein Bet } \mathrm{v} \text { I family (Bet V } \\
\text { I) } \\
\text { Carbohydrate and energy metabolism (7) }\end{array}$ & Cyt & $\begin{array}{l}\text { Malus } x \\
\text { domestica }\end{array}$ & 4590388 & $\begin{array}{l}5.01 \\
17,531 / \\
5.47\end{array}$ & $\begin{array}{l}4.94 \\
17,352 / \\
5.88\end{array}$ & 139 & 4 & \\
\hline 612 & Triosephosphate isomerase (TIM) & $\mathrm{Chl}$ & $\begin{array}{l}\text { Fragaria } x \\
\text { ananassa }\end{array}$ & 300659132 & $\begin{array}{l}33,733 / \\
7.64\end{array}$ & $\begin{array}{l}37,333 / \\
5.48\end{array}$ & 393 & 6 & in \\
\hline 614 & Triosephosphate isomerase (TIM) & $\mathrm{Chl}$ & Vitis vinifera & 300659132 & $33,733 /$ & $37,833 /$ & 263 & 4 & \\
\hline 619 & Triosephosphate isomerase (TIM) & $\mathrm{Chl}$ & $\begin{array}{l}\text { Stellaria } \\
\text { longipes }\end{array}$ & 300659296 & $\begin{array}{l}27 ., 710 / \\
5.54\end{array}$ & $\begin{array}{l}34,362 / \\
5,34\end{array}$ & 120 & 2 & \\
\hline 1183 & Beta-hexosaminidasc-like protein (Hexose) & $\mathrm{Chl}$ & $\begin{array}{l}\text { longipes } \\
\text { V. vinifera }\end{array}$ & 225450263 & $\begin{array}{l}5.54 \\
64,148 / \\
5,25\end{array}$ & $\begin{array}{l}50,345 / \\
858\end{array}$ & 131 & 3 & \\
\hline 467 & Mercapto-pyruvate sulfurtransferase (MST) & Cyt & Brassica napus & 253720703 & $\begin{array}{l}41,711 / \\
582\end{array}$ & $\begin{array}{l}43,282 / \\
5,9\end{array}$ & 292 & 6 & \\
\hline 181 & Malic enzyme (ME) & Cyt & $\begin{array}{l}\text { Ricinus } \\
\text { Compunis }\end{array}$ & 223546686 & $\begin{array}{l}3.02 \\
65,487 / \\
5,98\end{array}$ & $68,463 /$ & 469 & 9 & \\
\hline 155 & Transketolase 1 (TK) & $\mathrm{Chl}$ & $\begin{array}{l}\text { Capsicum } \\
\text { annumm }\end{array}$ & 3559814 & $\begin{array}{l}80,398 / \\
6.16\end{array}$ & $\begin{array}{l}84,483 / \\
6.11\end{array}$ & 262 & 9 & \\
\hline 1793 & $\begin{array}{l}\text { Transcription related (3) } \\
\text { RNA recognition motif (RRM) }\end{array}$ & $\mathrm{Sec}$ & V. vinifera & 297737424 & $\underset{5568}{21,608 /}$ & 67,394 & 106 & 3 & \\
\hline 860 & RNA recognition motif (RRM) & Nuc & Prunus avium & 34851124 & $\begin{array}{l}5.56 \\
17,374 /\end{array}$ & $\begin{array}{l}6.28 \\
17,363 / \\
5.99\end{array}$ & 1,03 & 13 & \\
\hline \multirow[t]{2}{*}{1708} & Nucleic acid binding protein (NABP) & Nuc & Zea mays & 162463757 & $\begin{array}{l}33,154 / \\
4.6\end{array}$ & $\begin{array}{l}36,713 / \\
4.53\end{array}$ & 269 & 3 & \\
\hline & Protein synthesis and turnover (5) & & & & & & & & \\
\hline 888 & $60 \mathrm{~S}$ acidic ribosomal protein (RP) & Cyt & Prunus dulcis & 111013714 & $11,408 /$ & $18,323 /$ & 296 & 5 & \\
\hline 150 & Heat shock protein 70 (HSP70) & Mit & P. trichocarpa & 222872861 & $75,412 /$ & $79,492 /$ & 634 & 13 & \\
\hline 164 & Heat shock protein 70 (HSP70) & Mit & $\begin{array}{l}\text { Phaseelus } \\
\text { Phylugoris }\end{array}$ & 257310566 & $\begin{array}{l}3.24 \\
72,721 /\end{array}$ & $\begin{array}{l}0.14 \\
74,523 /\end{array}$ & 648 & 12 & \\
\hline 420 & Heat shock protein 70 (HSP70) & Cyt & $\begin{array}{l}\text { Malus } x \\
\text { domestica }\end{array}$ & 257307291 & $\begin{array}{l}51,570 / \\
5,17\end{array}$ & $\begin{array}{l}3.01,532 / \\
4.78\end{array}$ & 114 & 7 & \\
\hline 479 & $\begin{array}{l}20 \text { S proteasome } \\
\text { Amino acid metabolism (11) }\end{array}$ & Cyt & $\begin{array}{l}\text { Medicago } \\
\text { truncatula }\end{array}$ & 217072126 & $\begin{array}{l}24,915 / \\
8.74\end{array}$ & $\begin{array}{l}45,384 / \\
5.09\end{array}$ & 704 & 9 & \\
\hline 594 & Cysteine protease $(\mathrm{CPs})$ & Vac & $\begin{array}{l}\text { Prunus } \\
\text { armeniaca }\end{array}$ & 2677828 & $\begin{array}{l}39,855 / \\
6.41\end{array}$ & $\begin{array}{l}37.442 / \\
4.78\end{array}$ & 78 & 4 & \\
\hline 200 & Acetohydroxyacid synthase, partial (AHAS) & $\mathrm{Chl}$ & G. $\max$ & 255689393 & $70,384 /$ & $73,483 /$ & 239 & 3 & \\
\hline 341 & Ankyrin repeat domain protein (ANK) & Sec & G. $\max$ & 17645766 & $29,128 /$ & $53,234 /$ & 268 & 3 & \\
\hline 729 & Ankyrin repeats (ANK) & Cyt & G. $\max$ & 255646471 & $38,027 /$ & $34,832 /$ & 271 & 5 & \\
\hline 1430 & Aspartate aminotransferase (AST) & Cyt & P. trichocarpa & 224074105 & $53,334 /$ & $32,392 /$ & 577 & 8 & \\
\hline 1533 & Asparagine synthetase (AS) & $\mathrm{Sec}$ & Vigna radiata & 2970051 & $\begin{array}{l}5.27 \\
25,750 / \\
562\end{array}$ & $\begin{array}{l}5.31 \\
37,564 / \\
6.31\end{array}$ & 295 & 5 & \\
\hline 342 & $\begin{array}{l}\text { Glutamate-1-semialdehyde 2,1-aminomutase } \\
\text { (GSA) }\end{array}$ & Chl & $\begin{array}{l}\text { Cucumis melo } \\
\text { subsp.Melo }\end{array}$ & 307136451 & $\begin{array}{l}50,339 / \\
6.16\end{array}$ & $\begin{array}{l}57,322 / \\
6.27\end{array}$ & 604 & 6 & \\
\hline 1348 & $\begin{array}{l}\text { Glutamate-1-semialdehyde 2,1-aminomutase } \\
\text { (GSA) }\end{array}$ & Chl & C. Melo & 307136451 & $\begin{array}{l}50,339 / \\
6.16\end{array}$ & $\begin{array}{l}57,478 / \\
663\end{array}$ & 549 & 6 & \\
\hline 335 & Glutamine synthetase (GS) & Cyt & Spiraed & 227478341 & $47,619 /$ & $56,425 /$ & 695 & 12 & \\
\hline 145 & Choline dehydrogenase (ChDH) & Vac & $\begin{array}{l}\text { mpponica } \\
\text { Prunus dulcis }\end{array}$ & 32482411 & 61, & $66,832 /$ & 881 & 12 & \\
\hline 471 & Thiosulfate sulfurtransferase (TST) & $\mathrm{Sec}$ & $\begin{array}{l}\text { Datisca } \\
\text { glomerata }\end{array}$ & 4406372 & $\begin{array}{l}4.89 \\
41,528 / \\
6.51\end{array}$ & $\begin{array}{l}47.81 \\
4.692 /\end{array}$ & 218 & 5 & \\
\hline \multirow[t]{2}{*}{604} & $\begin{array}{l}\text { Cell wall related (1) } \\
\text { Acidic endochitinase (Echi) }\end{array}$ & $\mathrm{Sec}$ & Arabidopsis & 166664 & $33,533 /$ & $37,456 /$ & 94 & 4 & \\
\hline & Cell div & & & & & & & & \\
\hline 1458 & FtsZ-like protein & $\mathrm{Chl}$ & V. vinifera & $\begin{array}{l}297737 / 5.0 \\
8\end{array}$ & $\begin{array}{l}37,442 / \\
5.19\end{array}$ & $\begin{array}{l}40,456 / \\
5.53\end{array}$ & 82 & 4 & إض \\
\hline
\end{tabular}

${ }^{a}$ Assigned spot number as indicated in Fig. $4 .{ }^{b}$ The name and functional categories of the proteins using MALDI TOF-TOF MS. ${ }^{~}$ Protein subcellular localization predicted by softwares (YLoc, LocTree3, Plant-mPLoc, ngLOC, and TargetP). Only the consistent predictions from at least two tools were accepted as a confident result listed in Additional file 3: Table S3. Chl, chloroplast; Cyt, cytoplasm; Mit, mitochondria; Nuc, nucleus; sec, secreted; vac, vacuole. ${ }^{d}$ The plant species that the peptides matched. ${ }^{e}$ Database accession numbers from NCBInr. ${ }^{f,}{ }^{9}$ Theoretical (e) and experimental (f) mass (kDa) and pl of identified proteins. Experimental values were calculated using Image Master 2D Platinum Software. Theoretical values were retrieved from the protein database. ${ }^{\text {T}}$ The Mascot score obtained after searching against the NCBInr database. 'The number of unique peptides identified for each protein. ${ }^{j}$ The mean values of protein spot volumes relative to total volume of all the spots. Four water deficit ( $0 \mathrm{~d}, 12 \mathrm{~d}$, and $24 \mathrm{~d})$ were performed. Error bars indicate mean \pm standard error (SE)

carboxylase/oxygenase large subunits (RuBisCO-LSU), a Ribose 5-phosphate isomerase (Rpi) and a chlorophyll a-b binding protein $(\mathrm{CAB})$ were accumulated under WD (Table 2, Fig. 8). Among them, Chlorophyll a-b binding protein (CAB), PSI light harvesting chlorophyll binding protein, is the intrinsic transmembrane antenna proteins (Lhca's) occurring in the reaction center of PSI. PSI is known to be the most efficient light converter in nature 

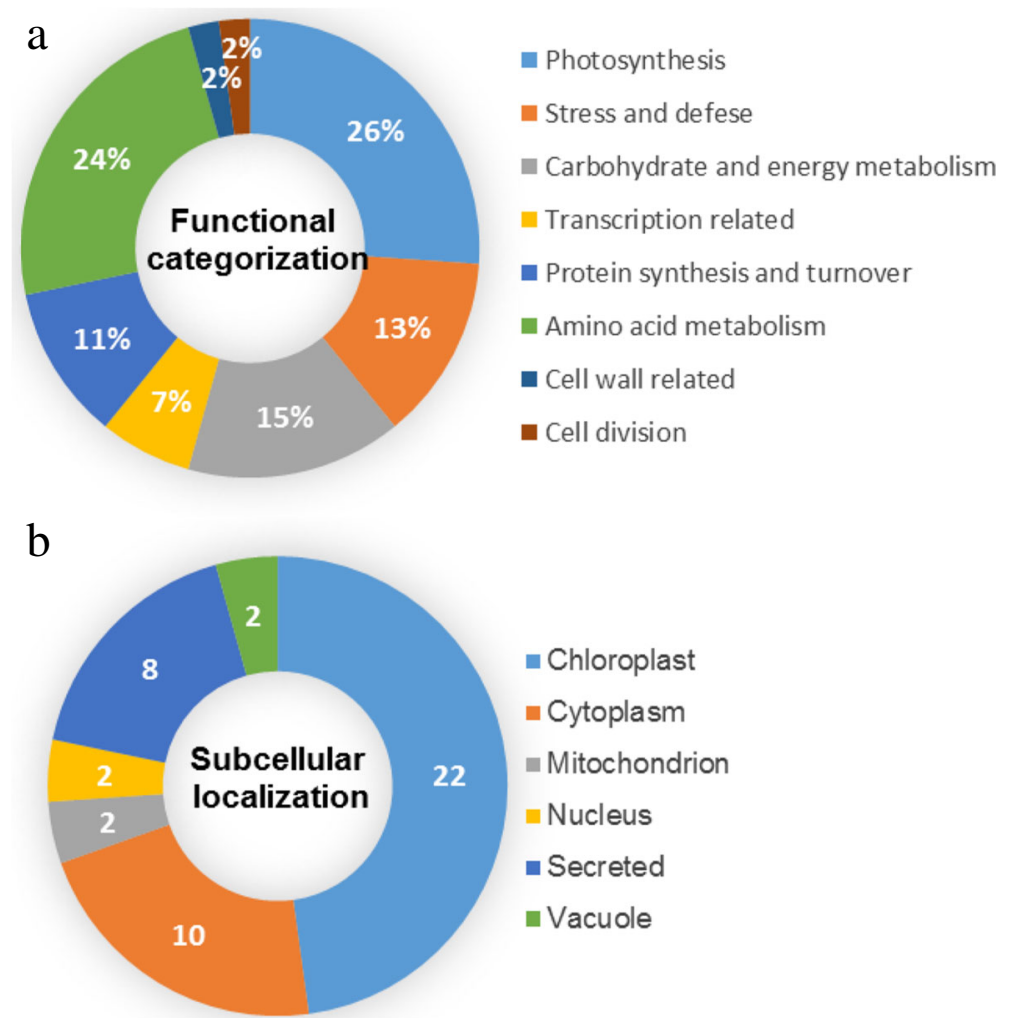

Fig. 5 Functional categorization and subcellular localization of the differentially expressed proteinsat different water deficit time points of $C$. humilileaves. a A total of 46 DEPs were classified into eight functional categories. The percentage of proteins in different functional categories is shown in the pie. $\mathbf{b}$ Subcellular localization categories of the identified proteins. The numbers of proteins with different locations are shown

since pigments in the PSI are not being quenched and energy transfer to the electron donor is very rapid [38]. Plastocyanin functions as an electron transfer agent between cytochrome $\mathrm{f}$ and $\mathrm{P} 00^{+}$from PSI [39]. We speculated that the increased $\mathrm{CAB}$ could transfer more excitation energy to the reaction center, and the accumulation of plastocyanin can donate more electrons to PSI. Finally, $\mathrm{CAB}$ with a higher abundance may help to minimize the energy loss caused by a reduction of PSII efficiency in the C. humilis response to moderate WD. In addition, CAs and $\mathrm{RuBisCO}$ were increased under 12 and $24 \mathrm{~d}$ WD in our study (Table 2). This indicated that WD promoted the $\mathrm{CO}_{2}$ assimilation, leading to the reprogramming of carbon metabolism. Carbonic anhydrase (CA), at the donor side of PSII, can aid to increase the concentration of $\mathrm{CO}_{2}$ within the chloroplast, which induces the carboxylation rate of RuBisCO [40]. RuBisCO is an important enzyme involved in the first major step of carbon fixation [41, 42]. It has been reported that overexpression of the CA in Arabidopsis resulted in an increase in plant biomass [41]. Previous proteomics studies have also revealed that the increase of Calvin cycle-related and light reaction proteins in Cynodon dactylon [18] and Malus [28].

\section{Regulation of osmostasis and redox homeostasis to cope with WD}

In our results, the accumulation of osmolytes in C. humilis enhanced the positive response to WD (Fig. 1b, c; Fig. 2). The regulation of osmostasis and redox homeostasis are critical for WD tolerance [43]. And WD affects cell membrane integrity and membrane lipid composition, resulting in the changes of REL and MDA content [36, 44]. This often happened in other species, such as Amygdalus mira (Koehne) Yü et $L u$ [44] and rice [45]. To cope with osmotic imbalance and protect membrane, diverse compatible osmolytes were accumulated in cells. On the other hand, proline is involved in radical scavenging, which has an important defensive role on resisting the WDinduced oxidative stress [46]. Total soluble sugar also acts as a crucial array of prevention and signals that is helpful to sense and control photosynthetic activity and ROS balance [47].

To minimize the damaging effects of ROS, plants have evolved various antioxidant enzymes defense pathways [48-50]. In this study, we found that the activities of several enzymes such as SOD, POD, CAT, GPX/GST, and four key enzymes of ascorbate-glutathione (AsA- 


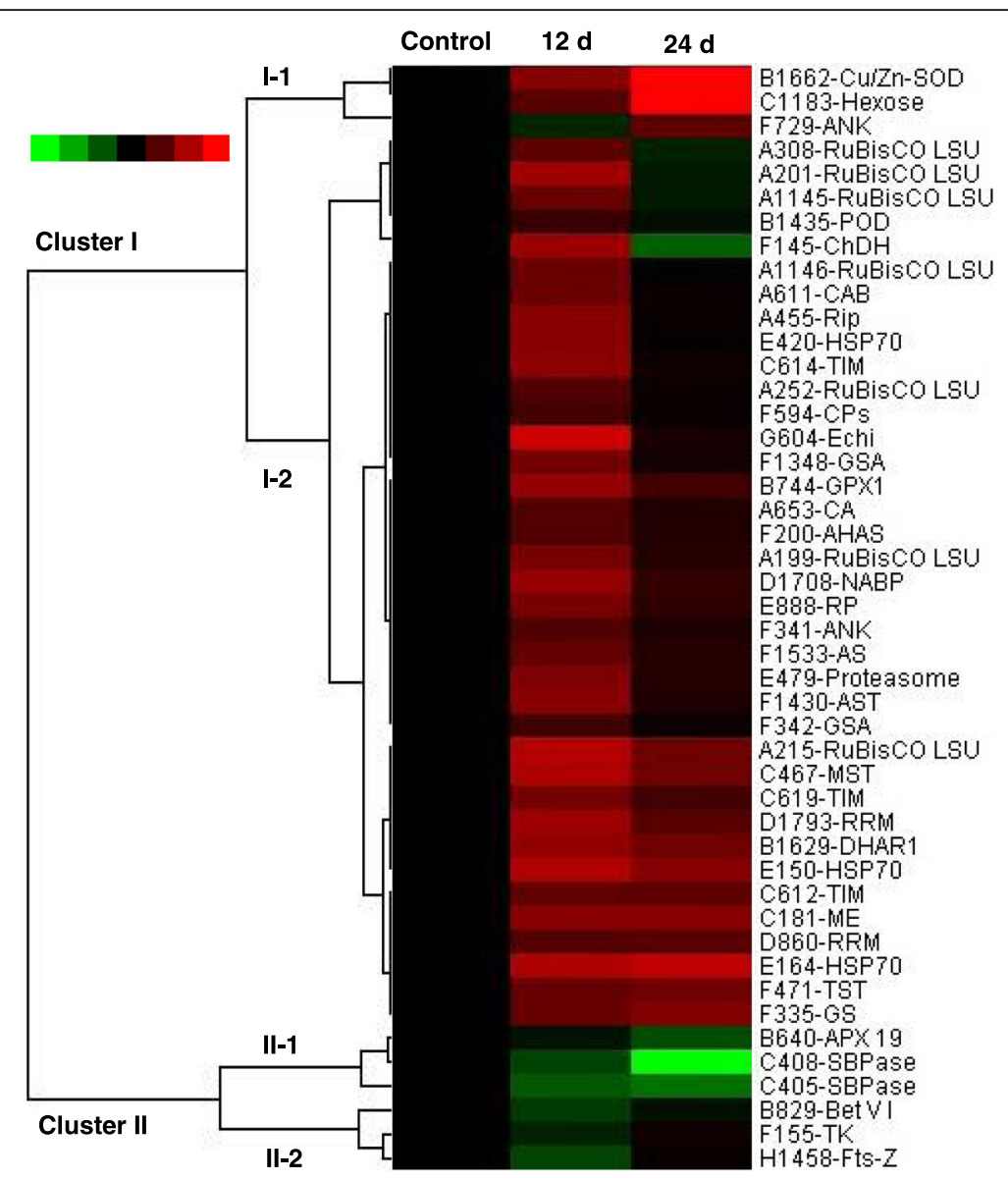

Fig. 6 Dendrogram of 46 differentially abundant proteins obtained by hierarchical clustering analysis. The three columns represent different drought treatment time points, including 0, 12, and 24 days. The rows represent individual proteins. Two main clusters (I and II) and subclusters of I and II (I-1, I-2, II-1, and II-2) are shown on the left side. Functional categories indicated by capital letters, spot numbers, and protein name abbreviations are listed on the right side. The scale bar indicates log (base2) transformed protein abundance ratios ranging from -3.0 to 3.0. The ratio was calculated as protein abundance at control divided by abundance each treatment, respectively. The increased and decreased proteins are represented in red and green, respectively. The color intensity increases with increasing abundant differences. Undetected proteins are indicated in gray. Abbreviations for functional categories: A, Photosynthesis; B, Stress and defense; C, Carbohydrate and energy metabolism; D, Transcription related; F, Protein synthesis and turnover; E, Amino acid metabolism; I, Cell wall related; J, Cell division. Detailed information on protein names and abbreviations can be found in Table 1

GSH) cycle, were affected by WD in C. humilis (Fig. 3). All these implied that AsA-GSH cycle and GPX/GST pathway were enhanced in C. humilis for WD tolerance [51]. Interestingly, the activity, expression, and abundance of some enzymes were inconsistent. Our proteomics results showed that the abundances of SOD, POD, DHAR, and GPX were increased, except that the abundances of APX were decreased. However, qRT-PCR results found that the expression of APX, DHAR, and GPX were increased (Fig. 7). Enzyme abundances may be inconsistent with their activities and expressions, as the activity is also modulated by the protein conformation and post-translational modifications. This indicated that ROS scavenging enzymes in $C$. humilis seedlings were modulated at both translational and post-translational levels for WD tolerance.
WD-responsive transcription, protein synthesis, and protein processing

In response to WD, plants exhibit quick switches from metabolic quiescent state to active state. In this study, our proteomics results revealed that two RNA recognition motif (RRM) and a nucleic acid binding protein (NABP) were increased at 12 and 24 days treatment. Besides, a ribosomal protein was increased at $12 \mathrm{~d}$ WD (Table 2). These indicated that RNA processing and protein synthesisregulated metabolic increase would be a positive response to WD. During gene expression, RNA processing by RNA chaperone is critical for keeping the proper RNA structure and function in response to WD [52].

We found three HSP 70s were WD-responsive in $C$. humilis at 12 and 24 d WD (Table 2). Protein folding and processing were active for preventing WD-induced 


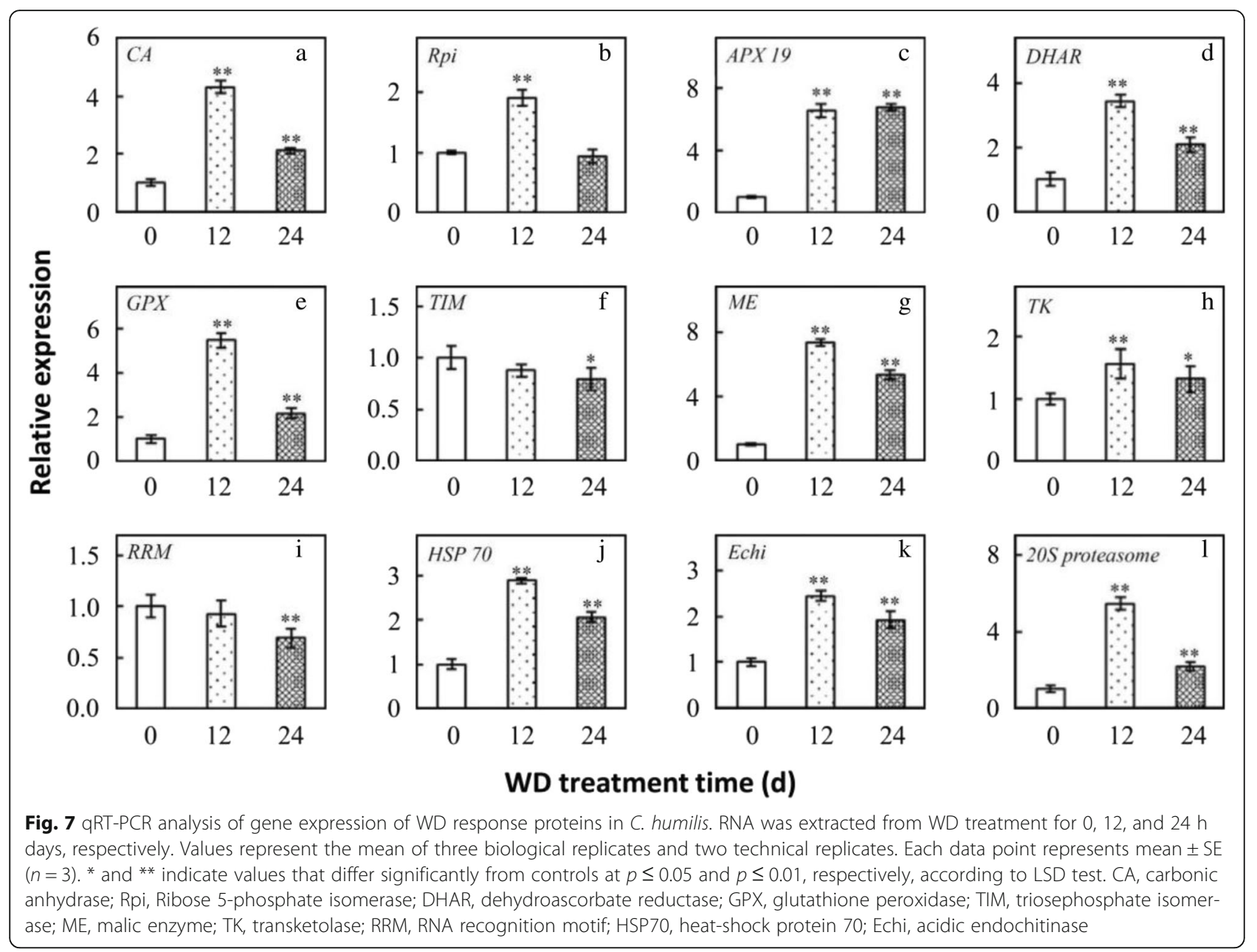

denature and incomplete aggregation [45], and HSP 70 belongs to the conservative family of molecular chaperones, and exists in all cells and organs, assisting protein folding, aggregation, translocation, and degradation [53]. Thus, the abundance of HSP 70 was significantly elevated in order to eliminate misfolded proteins. It has been also also revealed that $26 \mathrm{~S}$ proteasome increased in response to drought stress (Table 2), which is important to remove abnormal or damaged proteins and to control the levels of certain regulatory proteins during drought stress. Similar study also found in Hordeum vulgare [54] and Medicago sativa [55], respectively. These findings indicate that the enhancement of the ubiquitin/26S proteasome system is important for plants to cope with drought.

\section{Enhancement of carbohydrate supply and other specialized metabolism under WD}

In this study, five IDs were affected by WD, including three triosephosphate isomerases (TIM) involved in glycolysis, one transketolase (TK) involved in pentose phosphate pathways (PPP), and malic enzymes (ME) involved in TCA cycle (Table 2 and Fig. 8). The regulation of carbohydrate metabolism is an important strategy for plants to respond to WD [56]. TIM catalyzes the interconversion of glyceraldehyde-3-phosphate to dihydroxyacetone phosphate [57]. TK, key enzymes of the reductive and oxidative pentose phosphate pathways, are responsible for the synthesis of sugar phosphate intermediates [58]. Malic enzymes (MEs) involved in malate dehydrogenase $(\mathrm{MDH})$ system catalyze the L-malate decarboxylation reaction through their oxidation, and $\mathrm{MDH}$ catalyzethe interconversion of malate and oxaloacetate in areversible reaction of the TCA cycle have an important role in biochemical adaptation of plants to stress [59]. In addition, TK is considered to participate in pentosephosphate pathway. The pentose phosphate pathway is important to maintain carbon homoeostasis, to provide precursors for nucleotide and amino acid biosynthesis, and to provide reducing molecules for defeating oxidative stress Stincone et al. [60]. TK is the key enzyme of the non-oxidative branch of the pentose phosphate pathway of carbohydrate transformation [61]. Accumulation of TK would promote the enhancement of the non- 


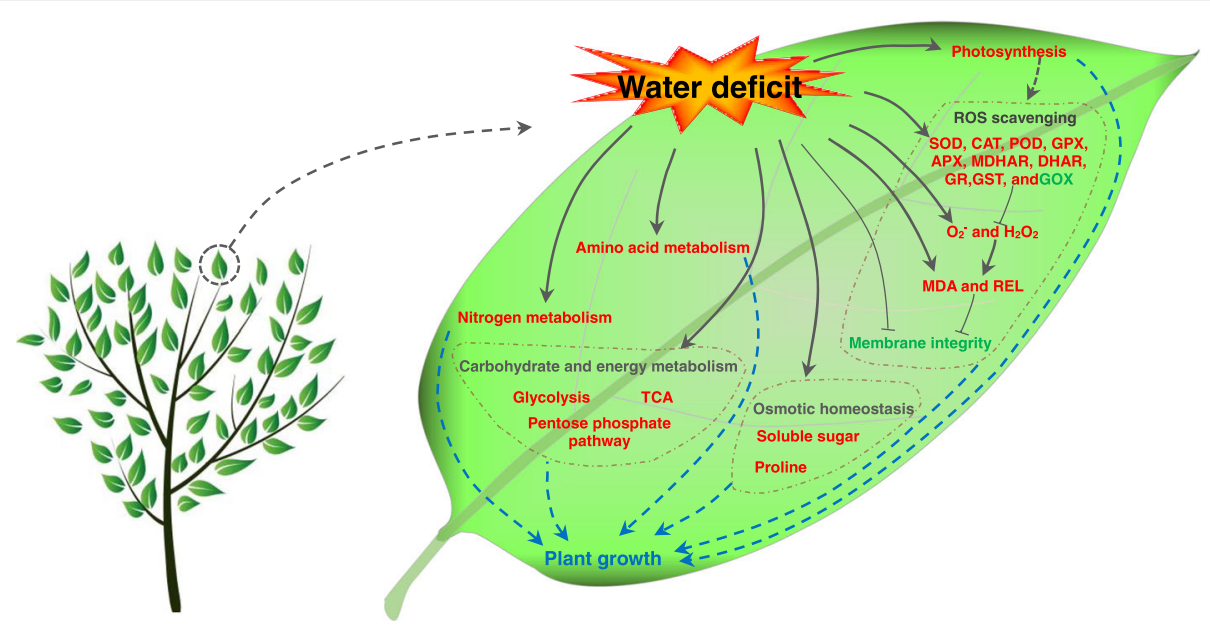

Fig. 8 Schematic presentation of systematic in C. humilileaves under water deficit. Water deficit inactive photosynthesis and lead to ROS burst, which resulting in the damage to cell membrane. To alleviate ROS toxicity, specific ROS scavenging pathways (e.g., APX, MDHAR, DHAR, GR, GST, GPX, POD, and CAT pathways) are induced. Water stress induces glycolysis, TCA cycle, and pentose phosphatepathway, providing carbon and energy in stressed leaves. In addition, the accumulation of various osmolytes, such as proline and soluble sugar are enhanced. Importantly, water deficit increases the nitrogen and amino acid metabolisms. Solid line with arrow and "T" shape line represent stimulation and inhibition, respectively. The red and green words indicate water deficit-induced and water deficit-reduced cellular processes, respectively. Dashed lines indicate indirect regulations. Abbreviations: APX, ascorbate peroxide; CAT, catalase; DHAR, dehydroascorbate reductase; $\mathrm{H}_{2} \mathrm{O}_{2}$, hydrogen peroxide; MDA, malondialdehyde; MDHAR, monodehydroascorbate reductase; GOX, glycoxylate oxidatase; GPX, glutathione peroxidase; GR, glutathione reductase; GST, glutathione-s-transferases; $\mathrm{O}_{2}^{-}$, superoxide anion; POD, peroxidase; REL, relative electrolyte leakage; ROS, reactive oxygen species; SOD, superoxide dismutase

oxidative branch, yielding ribose 5-phosphate for the synthesis of nucleic acids and amino acids accompanied by the production of NADPH, which is critical to maintain redox balance under stress situations [62]. Besides, our results are consistent with previous proteomic studies in Phaseolus vulgaris [63], rice [64], and wheat [65] under WD. Previously, enhancement of the glycolysis, PPP, and TCA has been found in several species in response to various stress conditions [66], which would provide more glyceraldehydes-3-phosphate (G3P), glucose-6-phosphate (G6P), NADPH, and erythrose-4-phosphate (E4P) that could be used to produce more ATP for maintaining the basic metabolism under stress [66, 67]. This might be a strategy for plant to enhance the ability of seedlings to survive under WD, which makes it possible for the cell to adapt to its metabolic needs.

\section{Rapid nitrogen and amino acid metabolisms are essential for WD}

Nitrogen assimilation is affected by abiotic stress in plants. In this process, exogenous absorbed nitrate is transformed to ammonium by nitrate reductase (NR) and nitrite reductase (NIR), and then assimilated by glutamine synthetase (GS) and glutamate synthase (GOGAT) into amino acids $[18,68]$. Our proteomics results revealed that 11 IDs were increased under WD (Table 2 and Fig. 8). Among them, the up-regulated 3-mercaptopyruvate sulfurtransferase (MST) implied that the efficiency of cellular redox state was increased. Related research showed that it catalyzes pyruvate transsulfuration from 3-mercaptopyruvate, which transamined from cysteine and also contributes to maintain the cellular redox state [69]. Similarly, the increased glutamine synthetase could be involved in the osmotic stress response, as glutamine synthetase is related to proline biosynthesis [70]. In addition, the accumulation of asparagine synthetase (AS) and aspartate aminotransferase (AST) in the present study might aid to nitrogen and amino acid metabolisms, leading to resist to WD response. AS and AST are key enzymes involved in carbon and nitrogen distribution [71]. AS is necessary for the production of nitrogen-rich amino acid asparagine, which is the primary of nitrogen metabolism [72-74]. Similarly, the previous study found that influence of over-expression of cytosolic AST on amino acid metabolism and defence responses against Botrytis cinerea infection in Arabidopsis thaliana [75].

\section{Conclusion}

This study is the first proteomic analysis in C. humilis response to WD to our knowledge. In general, we found some responsive pathways are pivotal under WD as shown in Fig. 8 by integrative analysis of all the results from physiological and proteomic analysis in C. humilis. Firstly, photosynthesis is strongly affected by WD. The increase of Calvin cycle-related and light reaction proteins may help to convert more light energy and minimize the energy loss caused by a reduction of PSII efficiency. In addition, the reestablishment of osmostasis and redox 
homeostasis, reprogramming of nuclear and chloroplast gene expression and protein processing are positive for C. humilis to WD. Furthermore, nitrogen and amino acid metabolisms lead to resist to WD response. These findings provide important information for understanding WD-responsive mechanisms in C. humilis seedlings.

\section{Additional files}

Additional file 1: Table S1. Primers used for the quantitative real-time RT-PCR analysis. (XLSX $9 \mathrm{~kb}$ )

Additional file 2: Table S2. Differentially expressed proteins and the sequences of peptides identified in C. humilis under WD using MALDI TOF-TOF MS. (XLSX $48 \mathrm{~kb}$ )

Additional file 3: Table S3. The subcellular localization prediction of the differentially expressed proteins identified in C. humilis under WD. (XLSX $30 \mathrm{~kb})$

\section{Abbreviations}

2-DE: Two dimensional electrophoresis; ACN: Acetonitrile; DTT: Dithiothreitol; GAPDH: Glyceraldehyde 3-phosphatedehydrogenase; MALDI-TOF/

TOF: Matrix-assisted laser desorption/ionization time-of-flight/time-offlight; RuBisCO: Ribulose bisphosphate carboxylase/oxygenase; TCA: Tricarboxylic acid; TFA: Trifluoroacetic acid

\section{Acknowledgments}

We acknowledge Shanghai AB Sciex Asia Pacific Application Support Center for its assistance in original data processing. This work was supported by Fundamental Research Funds for the Central Universities (2572015DA02), the National Natural Science Foundation of China (31170569, J1210053) and the Innovation Project of State Key Laboratory of Tree Genetics and Breeding (Northeast Forestry University).

\section{Funding}

This work was supported by Fundamental Research Funds for the Central Universities (2572015DA02), the National Natural Science Foundation of China (31170569, J1210053), the Innovation Project of State Key Laboratory of Tree Genetics and Breeding (Northeast Forestry University), and the Open Research Fund for Key Laboratory of Dairy Science (No.2015KLDSOF-06, Northeast Agricultural University).

\section{Availability of data and materials}

All the data generated or analyzed during this study are included in this published article and its additional files.

\section{Authors' contributions}

$Z Y$ designed the study and draft the manuscript; JR participated in analyzed data and drafted the manuscript; JR and LZ performed 2-DE and carried out MS analysis and performed protein identification. JR and YL carried out the photosynthesis and qRT-PCR analysis. LS and JW conceived the study analyzed experiments. XS conceived of, designed, and coordinated the study, and assisted with the writing of the manuscript. All authors read and approved the final manuscript.

\section{Competing interests}

The authors declare that they have no competing interests.

\section{Consent for publication}

Not applicable.

\section{Ethical approval and consent to participate}

Not applicable.

\section{Publisher's Note}

Springer Nature remains neutral with regard to jurisdictional claims in published maps and institutional affiliations.

\section{Author details}

1Department of Genetics, College of Life Science, Northeast Forestry University, Harbin 150040, People's Republic of China. ${ }^{2}$ State Key Laboratory of Tree Genetic sand Breeding, Northeast Forestry University, Harbin 150040, People's Republic of China. ${ }^{3}$ Horticulture Department, College of Horticulture, Shenyang Agricultural University, No. 120 Dongling Road, Shenhe District, Shenyang 110866, People's Republic of China. ${ }^{4}$ College of Food Science; Key Laboratory of Dairy Science, Ministry of Education, Synergetic Innovation Center of Food Safety and Nutrition, Northeast Agricultural University, Harbin, Heilongjiang 150030, People's Republic of China. ${ }^{5}$ Forest Engineering and Environment Research Institute of Heilongjiang Province, No. 134 Haping Road, Nangang District, Harbin, Heilongjiang 150081, People's Republic of China.

Received: 23 November 2016 Accepted: 26 April 2017

Published online: 08 May 2017

\section{References}

1. Bray EA. Plant responses to water deficit. Trends Plant Sci. 1997;2:48-54.

2. Zhu JK. Salt and drought stress signal transduction in plants. Annu Rev Plant Biol. 2002;53:247-73.

3. Farah D, Ashurosh KP, Sanjay R, Ashwarya M, Ruchi S, Sharma YK, Pramod AS, Vivek P. Physiological and proteomic responses of cotton (Gossypium herbaceum L.) to drought stress. Plant Physiol Biochem. 2012;53:6-18.4.

4. Sircelj H, Tausz E, Grill M. Detecting different levels of drought stress in apple trees (Malus domestica Borkh.) with selected biochemical and physiological parameters. Sci Hortic. 2007;133:362-9.

5. Shuvasish C, Piyalee P, Lingaraj S, Sanjib KP. Reactive oxygen species signaling in plants under abiotic stress. Plant Signal Behav. 2013;8(4):23681-66.

6. Reddy R, Chaitanya V, Vivekanandan M. Drought-induced responses of photosynthesis and antioxidant metabolism in higher plants. J Plant Physiol. 2004;161:1189-202.

7. Upadhyaya H, Khan MP. Hydrogen peroxide induces oxidative stress in detached leaves of Oryza sativa L. Gen Appl Plant Physiol. 2007;33:83-95.

8. Miller G, Suzuki N, Ciftci-Yilmaz S, Mittler R. Reactive oxygen species homeostasis and signalling during drought and salinity stresses. Plant Cell Environ. 2010;33:453-67.

9. Faize M, Burgos L, Faize L, Piqueras A, Nicolass E. Involvement of cytosolic ascorbate peroxidase and $\mathrm{Cu} / \mathrm{Zn}$-superoxide dismutase for improved tolerance against drought stress. J Exp Bot. 2011;62:2599-613.

10. Good AG, Zaplachinski ST. The effects of drought stress on free amino acid accumulation and protein synthesis in Brassica napus. Physiol Plant. 1994;90:9-14.

11. Villar-Salvador P, Planelles $R$, Oliet J, Peñuelas-Rubira JL, Jacobs DF, Gonzalez M. Drought tolerance and transplanting performance of holm oak (Quercus ilex) seedlings after drought hardening in the nursery. Tree Physiol. 2004;24: 1147-55.

12. Corcuera L, Morales F, Abadia A, Gil-Pelegrin E. Seasonal changes in photosynthesis and photoprotection in a Quercus ilex subsp. ballota woodland located in its upper altitudinal extreme in the Iberian Peninsula. Tree Physiol. 2005;25:599-608.

13. Martínez F, Arif A, Nebauer SG, Bueso E, Ali R, Montesinos C, et al. A fungal transcription factor gene is expressed in plants from its own promoter and improves drought tolerance. Planta. 2015;242:39-52.

14. Hu W, Huang C, Deng X, Zhou S, Chen L, Li Y, et al. TaASR1, a transcription factor gene in wheat, confers drought stress tolerance in transgenic tobacco. Plant Cell Environ. 2013;36:1449-64.

15. Jensen MK, Lindemose S, De Masi F, Reimer JJ, Nielsen M, Perera V, et al. ATAF1 transcription factor directly regulates abscisic acid biosynthetic gene NCED3 in Arabidopsis thaliana. FEBS Open Bio. 2013;3:321-7.

16. Washburn MP, Koller A, Oshiro G, Ulaszek RR, Plouffe D, Deciu C, Winzeler E, Yates JR. Protein pathway and complex clustering of correlated mRNA and protein expression analyses in Saccharomy cescerevisiae. Proc Natl Acad Sci. 2003;100:3107-12.

17. Deyholos MK. Making the most of drought and salinity transcriptomics. Plant Cell Environ. 2010;33:648-54.

18. Wang XL, Cai XF, Xu CX, Wang QH. Dai SJ. Drought-Responsive Mechanisms in plant leaves revealed by proteomics. 2016;17:1706.

19. Gazanchian A, Hajheidari M, Sima NK, Salekdeh GH. Proteome response of Elymus elongatum to severe water stress and recovery. J Exp Bot. 2007:58:291-300. 
20. Huang $B, D a C o s t a ~ M$, Jiang $Y$. Research advances in mechanisms of turfgrass tolerance to abiotic stresses: From physiology to molecular biology. Plant Sci. 2014;33:141-89.

21. Shi H, Ye T, Chan Z. Comparative proteomic responses of two bermudagrass (Cynodon dactylon (L). Pers.) varieties contrasting in drought stress resistance. Plant Physiol Biochem. 2014;82:218-28.

22. Song XS, Shang ZW, Yin ZP, Ren J, Sun MC, Ma XL. Mechanism of xanthophyllcycle-mediated photoprotection in Cerasus humilis seedlings under water stress and subsequent recovery. Photosynthetica. 2011;49:523-30.

23. Yin ZP, Shang ZW, Wei C, Ren J, Song XS. Foliar sprays of photosynthetic bacteria improve the growth and anti-oxidative capability on Chinese Dwarf Cherry Seedlings. J Plant Nutr. 2012;35:840-53.

24. Yin ZP, Li S, Ren J, Song XS. Role of spermidine and spermine in alleviation of drought-induced oxidative stress and photosynthetic inhibition in Chinese dwarf cherry (Cerasus humilis) seedlings. Plant Growth Regul. 2014;209-18.

25. Gong M, Li Y-J, Chen S-Z. Abscisic acid-induced thermotolerance in maize seedlings is mediated by calcium and associated with antioxidant systems. J Plant Physiol. 1998;153:488-96.

26. Lu CM, Jiang GM, Wang BS, Kuang TY. Photosystem II photochemistry and photosynthetic pigment composition in saltadapted halophyte Artimisia anethifolia grown under outdoor conditions. J Plant Physiol. 1998;160:403-8.

27. Porcel R, Ruiz-Lozano JM. Arbuscular mycorrhizal influence on leaf water potential, solute accumulation, and oxidative stress in soybean plants subjected to drought stress. J Exp Bot. 2004;55:1743-50.

28. Ibrahim MH, Jaafar HZE. Primary, secondary metabolites, $\mathrm{H}_{2} \mathrm{O}_{2}$, malondialdehyde and photosynthetic responses of Orthosiphon stimaneus benth. to different irradiance levels. Molecules. 2012;17:1159-76.

29. Yan B, Dai Q, Liu X, Huang S, Wang Z. Flooding-induced membrane damage, lipid oxidation and activated oxygen generation in corn leaves. Plant Soil. 1996;179:261-8.

30. Suo J, Zhao Q, Zhang Z, Chen S, Cao J, Liu G, et al. Cytological and proteomic analyses of Osmunda cinnamomea germinating spores reveal characteristics of fern spore germination and rhizoid tip growth. Mol Cell Proteomics. 2015;14:2510-34.

31. Bradford MM. A rapid and sensitive method for the quantitation of microgram quantities of protein utilizing the principle of protein-dye binding. Anal Biochem. 1976;72:248-54

32. Wang X, Chen S, Zhang H, Shi L, Cao F, Guo L, et al. Desiccation tolerance mechanism in resurrection fern-ally Selaginella tamariscina revealed by physiological and proteomic analysis. J Proteome Res. 2010;9:6561-77.

33. Zhu M, Simons B, Zhu N, Oppenheimer DG, Chen S. Analysis of abscisic acid responsive proteins in Brassica napus guard cells by multiplexed isobaric tagging. J Proteomics. 2010;73:790-805.

34. Yu J, Chen S, Zhao Q, Wang T, Yang C, Diaz C, et al. Physiological and proteomic analysis of salinity tolerance in Puccinellia tenuiflora. J Proteome Res. 2011;10:3852-70.

35. Livak KJ, Schmittgen TD. Analysis of relative gene expression data using real-time quantitative PCR and the 2(-Delta Delta C(T)) method. Methods. 2001;25:402-8.

36. Merewitz EB, Gianfagna T, Huang B. Protein accumulation in leaves and roots associated with improved drought tolerance in creeping bentgrass expressing an ipt gene for cytokinin synthesis. J Exp Bot. 2011;62:5311-33.

37. Sharkey TD, Bernacchi CJ, Farquhar GD, Singsaas EL. Fitting photosynthetic carbon dioxide response curves for C3 leaves. Plant Cell Environ. 2007;30: 1035-40.

38. Van Amerongen $\mathrm{H}$, Croce R. Light harvesting in photosystem II. Photosynth Res. 2013;116:251-63.

39. Farkas D, Hansson Ö. Thioredoxin-mediated reduction of the photosystem i subunit PsaF and activation through oxidation by the interaction partner plastocyanin. Federation of European Biochemical Societies. 2011;585:1753-8.

40. Badger MR, Price GD. The Role of Carbonic Anhydrase in Photosynthesis Plant Physiol Plant Mol Biol. 1994;45:369-92.

41. Feller U, Anders I, Demirevska K. Degradation of rubisco and other chloroplast proteins under abiotic stress. Plant Physiol. 2008;34:5-18.

42. Spreitzer RJ, Salvucci ME. Rubisco: structure, regulatory interactions, and possibilities for a better enzyme. Plant Biol. 2002;53:449-75.

43. Brossa R, Pinto-Marijuan M, Francisco R, Lopez-Carbonell M, Chaves MM, Alegre L. Redox proteomics and physiological responses in Cistus albidus shrubs subjected to long-term summer drought followed by recovery. Planta. 2015;241:803-22.
44. Cao Y, Luo Q, Tian Y, Meng F. Physiological and proteomic analyses of the drought stress response in Amygdalus Mira (Koehne) Yü et Lu roots. BMC Plant Biology. 2017;17-53.

45. Jin K, Gang C, Mi-Jeong Y, Ning Z, Daniel D, John EE, Hongbo S, Sixue C. Comparative proteomic analysis of Brassica napus in response to drought stress. J Proteome Res. 2015:14:3068-81.

46. Kaul S, Sharma S, Mehta I. Free radical scavenging potential of L-proline: evidence from in vitro assays. Amino Acids. 2008:34:315-20.

47. Couée I, Sulmon C, Gouesbet G, El Amrani A. Involvement of soluble sugars in reactive oxygen species balance and responses to oxidative stress in plants. J Exp Bot. 2006;57:449-59.

48. Noctor $\mathrm{G}$, Mhamdi A, Foyer $\mathrm{CH}$. Update on the physiology of reactive oxygen metabolism during drought the roles of reactive oxygen metabolism in drought: not so cut and dried. Plant Phisiol. 2014;164:1636-48.

49. Zhang H, Han B, Wang T, Chen S, Li H, Zhang Y, et al. Mechanisms of plant salt response: Insights from proteomics. J Proteome Res. 2012;11:49-67.

50. Jithesh MN, Prashanth SR, Sivaprakash KR, Parida AK. Antioxidative response mechanisms in halophytes: their role in stress defence. J Genet. 2006;85:237-54.

51. Gechev TS, Benina M, Obata T, Tohge T, Sujeeth N, Minkov I, et al. Molecular mechanisms of desiccation tolerance in the resurrection glacial relic Haberlea rhodopensis. Cell Mol Life Sci. 2013;70:689-709.

52. Jabeen B, Naqvi S, Mahmood T, Sultana T, Arif M, Khan F. Ectopic expression of plant RNA chaperone offering multiple stress tolerance in E. coli. Mol Biotechnol. 2017;59:66-72.

53. Wang W, Vinocur B, Shoseyov O, Altman A. Role of plant heat-shock proteins and molecular chaperones in the abiotic stress response. Trends Plant Sci. 2004;9:244-52.

54. Ghabooli M, Khatabi B, Ahmadi FS, Sepehri M, Mirzaei M, Salekdeh GH. Proteomics study reveals the molecular mechanisms underlying water stress tolerance induced by Piriformospora indica in barley. J Proteom. 2013;94: 289-301.

55. Aranjuelo I, Molero G, Erice G, Avice JC, Nogues S. Plant physiology and proteomics reveals the leaf response to drought in alfalfa (Medicago sativa L.). J Exp Bot. 2011:62:111-23.

56. Keller F, Ludlow MM. Carbohydrate metabolism in drought-stressed leaves of pigeonpea (Cajanus cajan). J Exp Bot. 1993:44:1351-9.

57. Zaffagnini M, Fermani S, Costa A, Lemaire SD, Trost P. Plant cytoplasmic GAPDH: redox post-translational modifications and moonlighting properties. Front Plant Sci. 2013;4:450

58. Bernacchia G, Schwall G, Lottspeich F, Salamini F, Bartels D. The transketolase gene family of the resurrection plant Craterostigma plantagineum: differential expression during the rehydration phase. EMBO J. 1995;14:610-8.

59. Babayev H, Mehvaliyeva U, Aliyeva M, Feyziyev Y, Guliyev N. The study of NAD-malic enzyme in Amaranthus cruentus L. under drought. Plant Physiol Biochem. 2014:81:84-9.

60. Stincone A, Prigione A, Cramer T, Wamelink MMC, Campbell K, Cheung E, et al. The return of metabolism: Biochemistry and physiology of the pentose phosphate pathway. Biol Rev. 2015;90:927-63.

61. Kochetov GA, Solovjeva ON. Structure and functioning mechanism of transketolase. Biochim Biophys Acta - Proteins Proteomics. 1844;2014:1608-18.

62. Pang Q, Zhang A, Zang W, Wei L, Yan X. Integrated proteomics and metabolomics for dissecting the mechanism of global responses to salt and alkali stress in Suaeda corniculata. Plant Soil. 2016:402:379-94.

63. Zadražnik T, Hollung K, Egge-Jacobsen W, Meglič V, Šuštar-Vozlič J. Differential proteomic analysis of drought stress response in leaves of common bean (Phaseolus vulgaris L.). J Proteomics. 2013;78:254-72.

64. Salekdeh GH, Siopongco J, Wade LJ, Ghareyazie B, Bennett J. A proteomic approach to analyzing drought- and salt-responsiveness in rice. F Crop Res. 2002;76:199-219.

65. Bazargani MM, Sarhadi E, Bushehri AAS, Matros A, Mock HP, Naghavi MR, et al. A proteomics view on the role of drought-induced senescence and oxidative stress defense in enhanced stem reserves remobilization in wheat. J Proteomics. 2011;74:1959-73.

66. Henkes S, Sonnewald U, Badur R, Flachmann R, Stitt M. A small decrease of plastid transketolase activity in antisense tobacco transformants has dramatic effects on photosynthesis and phenylpropanoid metabolism. Plant Cell. 2001;13:535-51.

67. Fahrendorf T, Ni W, Shorrosh BS, Dixon RA. Stress responses in alfalfa (Medicago sativa L.) XIX. Transcriptional activation of oxidative pentose phosphate pathway genes at the onset of the isoflavonoid phytoalexin response. Plant Mol Biol. 1995;28:885-900. 
68. Kosová K, Vitámvás P, Práśil IT, Renaut J. Plant proteome changes under abiotic stress - contribution of proteomics studies to understanding plant stress response. J Proteomics. 2011;74:1301-22.

69. Shibuya N, Mikami Y, Kimura Y, Nagahara N, Kimura H. Vascular endothelium expresses 3-mercaptopyruvate sulfurtransferase and produces hydrogen sulfide. J Biochem. 2009;146:623-6.

70. Silveira JAG, Viégas RDA, da Rocha IMA, Moreira ACDOM, Moreira RDA, Oliveira JTA. Proline accumulation and glutamine synthetase activity are increased by salt-induced proteolysis in cashew leaves. J Plant Physiol. 2003; 160:115-23.

71. Xu G, Fan X, Miller AJ. Plant nitrogen assimilation and use efficiency. Annu Rev Plant Biol. 2012;63:153-82.

72. Hwang IS, An SH, Hwang BK. Pepper asparagine synthetase 1 (CaAS1) is required for plant nitrogen assimilation and defense responses to microbial pathogens. Plant J. 2011;67:749-62.

73. Boaretto LF, Carvalho G, Borgo L, Creste S, Landell MGA, Mazzafera P, et al. Water stress reveals differential antioxidant responses of tolerant and nontolerant sugarcane genotypes. Plant Physiol Biochem Elsevier Masson SAS. 2014;74:165-75.

74. Lam HM, Coschigano K, Schultz C, Melo-Oliveira R, Tjaden G, Oliveira I. Use of Arabidopsis mutants and genes to study amide amino acid biosynthesis. Plant Cell. 1995;7:887.

75. Brauc S, De Vooght E, Claeys M, Angenon G. Influence of over-expression of cytosolic aspartate aminotransferase on amino acid metabolism and defence responses against Botrytis cinerea infection in Arabidopsis thaliana. J Plant Physiol. 2011;168:1813-9.

\section{Submit your next manuscript to BioMed Central} and we will help you at every step:

- We accept pre-submission inquiries

- Our selector tool helps you to find the most relevant journal

- We provide round the clock customer support

- Convenient online submission

- Thorough peer review

- Inclusion in PubMed and all major indexing services

- Maximum visibility for your research

Submit your manuscript at www.biomedcentral.com/submit 